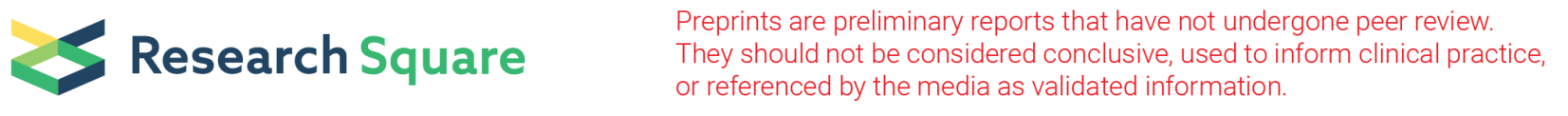

\title{
Mixed Method Synthesis of Cognitive interviews with Kenyan peripartum adolescents: Testing EPDS and PHQ questionnaires in Nairobi primary care settings
}

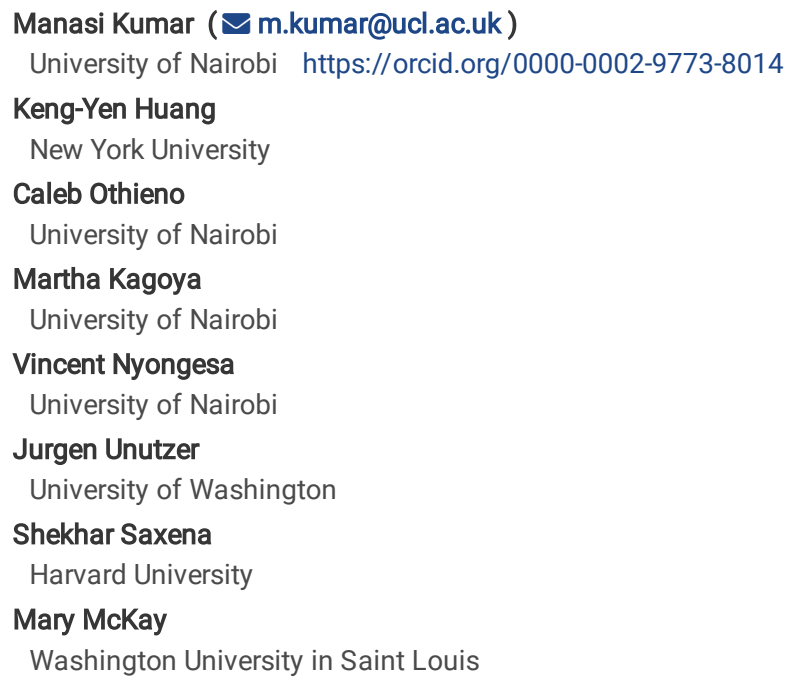




\section{Abstract}

Background: Cognitive interviewing is a well-recognized methodology to identify clinical and commonsensical relevance of mental health questionnaire items by our research participants. Depression is amongst the most common condition impacting pregnant and parenting adolescents in sub-Saharan Africa (SSA). In Kenya, studies have reported depression prevalence estimates of $12-50 \%$ in peripartum adolescents. While young people prefer using English, there has not been enough data to point to how well they respond to Kiswahili translations of the commonly used tools.

Method: Thirty-two participants between ages 14-18 years were approached and through informed consent for them to participate. We used Edinburgh Postnatal Depression Scale (EPDS) and Patient Health Questionnaire-9 (PHQ-9) in English and Kiswahili versions to carry out the interviews and were coded along four domains of comprehension, retrieval, judgement and patient response. Scores were tabulated for all participants and simple reliability analyses were offered. The interviews were discussed within the team and tables were shared between three raters for further consensus. The interview transcripts were analyzed manually using thematic analysis.

Discussion: We found that adolescents had challenges in fully understanding items in both set of tools however, EPDS was better received than PHQ-9. Psychometrically, EPDS English version and Kiswahili versions fared better than the PHQ-9 English and Kiswahili versions. PHQ-9 presented considerable issues with regards to semantic clarity however had simpler response options in comparison to EPDS which was more experientially appropriate, but response options were not simple. On our thematic analysis we felt that the adolescents were significantly challenged by the new, unanticipated pregnancy or motherhood experience. Poverty, poor partner support, discord with parents and distress in the family, and traumatic end of supportive and helpful relationships were the notable problems.

Conclusion: While sensitive cross-cultural translations for the commonly used open access depression tools is critical, it is also pertinent to understand whether these are developmentally appropriate. Our participants had multiple psychosocial and material challenges that necessitate measures sensitive to their age, social context and health experiences. Additionally, we felt that both the tools may not be suitable for self-administration and may need involvement of a case worker or community health worker.

\section{Background}

Depression continues to be the second most critical psychiatric disorder contributing to disability in young women in SSA (1). As peripartum disorders and mental disorders intersect, the public health significance of appropriate timing and tools for assessing peripartum mental health disorders is critical for young girls. Prolonged depression or poor mental health has long term consequences for adolescents as it impacts maternal general health, child development, family functioning.

Studies have shown that early diagnosis and screening at primary health care settings in Low -and-Middle Income Countries (LMICs) can offset significant later life perinatal mental health burden. Ensuring that whilst tools be psychometrically robust, clinically relevant, these also need to be well-understood by adolescents and be offered in languages that offer them maximum flexibility in expressing themselves.

\section{Cultural and anthropological explanations of Depression}

Depression is a multilevel phenomenon and culture impinges not only to inform the biological and environmental factors such as heredity, poverty, marital stress but also embeds the larger social milieu in which depression is experienced by an individual (2). Mental health in itself is an extension of one's cultural phenomena and neither culture nor mental life are static in any way. Similarly, the sociological aspects of depression are both influenced by and also influence the other biological and psychological aspects of people's lives. Engel's work in 1980 on biopsychosocial approach has widely been accepted today (3).

Anthropologists have investigated discrimination related to mental health and other stigmatized disorders (4) and ways in which individuals conceptualize their distress, express distress through idioms and colloquial terms and use culturally sanctioned and endorsed ways of resolving their problems. Depression is well known to be a condition that is expressed through somatic idioms and in many non-Western cultural contexts, it is represented by bodily aches, headaches and such symptoms. Cross-cultural psychologists such as Marsella have questioned whether depression is a mood, a symptom, or a syndrome and if it has static features by which it can be identified (5). Cultural experiences can embed in psychophysiological manners impacting our cognition, emotions and interpersonal relationships (6). In the context of this study, pregnant adolescents bring with them certain sociocultural experiences - both good and bad, that impact their mood and mental health.

Cognitive interviewing and qualitatively understanding participants' perspectives on depression including through the use of structured questionnaires assists in learning about the beliefs, individual stressors and ways in which depression comes to form in the illness narrative (6).

\section{Public Health Significance of Diagnosing Depression}

The burden of mental disorders is by now well established in several published reports. Depressive disorders are prevalent, disabling, often chronic illnesses, which cause a high economic burden for society, related to both direct and indirect costs (7). Depression is acknowledged as a major public health problem by many national governments and international agencies (8). There have been concerns that in the LMICs the diagnosis of depression despite refinements in symptom checklists continue to be assessed without reference to stress, cultural context, developmental stage, personality or coping. The World Health Organization's Mental Health Gap Action Program- Intervention Guide (mhGAP-IG) provides modules on mental disorder diagnosis assessment, management and follow-up (9). These guidelines recommend that early screening as part of routine primary health care can enable timely detection and simple self-care and social support strengthening interventions that can address depression. Depression was until recently the leading cause of disability for both males and 
females, the burden of depression remains $50 \%$ higher for females than males (10). Currently, depression is the second leading cause of Disability-Adjusted Life Years (DALYS) following anxiety as the leading cause (1).

Studies on Local Burden Associated with Adolescent peripartum Depression

In a study conducted in Nairobi by Osok et al to screen for depression among women attending antenatal clinics for a sample size of ( $\mathrm{n}=176$ ); it was found out that $58 \%$ showed likelihood of depression using EPDS. This was then confirmed using PHQ-9 and $33 \%(n=58)$ positively screened for clinical depression (11). In Kenya a study conducted by Ongeri et al found that the prevalence of depression using EPDS was 18.7\% (95\% Cl: 13.3-25.5) (12). Another study conducted in Addis Ababa, Ethiopia by Biratu et al on antenatal depression in pregnant women using EPDS scale ( $n=393)$, found prevalence of antenatal depression to be $24.94 \%(95 \%$ Cl: 20.85-29.30\%) (13). In another Ethiopian study conducted by Dibaba et al pregnant women ( $n=627)$; the prevalence of depressive symptoms during pregnancy on EPDS scale was 19.9\% (95\% Cl: 16.8-23.1\%) (14) and Govender et al in South Africa found ( $\mathrm{n}=326)$ the prevalence of depression among the pregnant participants was found to be $15.9 \%$ using EPDS (15).

\section{Cognitive interviewing as a method and theoretical approach}

Cognitive interviewing of patients for whom the questionnaire is intended proved a valuable tool to increase its face and content validity (16). It is underpinned by the assumption that respondents are able to provide verbal reports of their thought processes (17). Cognitive Interviewing (Cl) refers to a method used in research to help the researcher identify various sources of confusion in assessment items and to assess validity evidence on the basis of content and response processes (18). The process involves scrutinizing the question-response to determine how well a question performs in capturing a particular concept when asked to respondents. The goal is for the EPDS 10 items and PHQ-9 items to capture the scientific intent of the question and, at the same time make sense to respondents.

\section{Method}

\section{Participants, Setting and Ethical Clearance}

The study was approved by Kenyatta National Hospital/University of Nairobi ethical review committee (approval no. P694/09/2018). Approval was also received from Nairobi County Health Directorate (approval no. CMO/NRB/OPR/VOL1/2019/04) and subsequently permit from Kenyan National Commission for Science, Technology and Innovation (NACOSTI/P/19/77705/28063) was sought.

\section{Tools, their translations and psychometric properties}

This study used a mixed method design to interpret data collected in two health care facilities, in Nairobi County- Kenya in 2019. Data collection was through use of questionnaires interpreted quantitatively and semi-structured interviews (qualitative) capturing their responses, comprehension, retrieval and judgment of the questions in the quantitative questionnaires pinned in cognitive interviewing theory. The tools used were Edinburg Postpartum Depression Scale (EPDS) and Patient Health Questionnaire (PHQ-9) each with both English and Kiswahili Versions on 32 participants from July-November (5 months).

\section{The Edinburgh Postpartum Depression Scale (EPDS)}

EPDS was developed by Cox, Holden, Sagovsky in the year 1987 by Scottish health centers in Edinburgh and Livingston (19). It was developed for screening postpartum women in outpatient, home visiting settings, or at the $6-8$ weeks postpartum examination. The tool is comprised of 10 questions and can be completed within five (5) minutes using one-week recall. Responses are scored 0, 1, 2, or 3 depending on the severity of the symptom. Items marked with an asterisk $(*)$ are reverse scored (i.e., 3, 2, 1, and 0), and total score is a summation of the 10 item responses. EPDS is structured into four severity ranges: 1 ) None or minimal depression (0-6), 2) Mild depression (7-13), 3) Moderate depression (14-19), 4) Severe depression (19-30) and a need to refer or follow up suicidal risk.

In the United States it has been applied on various populations such as the women and Spanish women. In this study, a sample of 1516 postpartum women completed the EPDS and the Beck Depression Inventory (BDI). Severity ranges in this study matched those of the Beck Depression Inventory with majority of the women between a score range of 7 and 13 (minimally depressed) likely to be mild depression with other tools measuring depression severity. This classification allows proper referral and treatment decisions to be made (20).

The EPDS has been validated in different cultures showing its importance in mitigating long lasting effects for mothers, their children and society at large (21). It has been widely tested globally including countries in Sub-Saharan Africa (SSA) (22,23). Translations in Kiswahili developed in Kenya, where EPDS was translated into Kiswahili and it is the version that is being used here (24).

\section{Patient Health Questionnaire-9 (PHQ-9)}

The patient Health Questionnaire-9 (PHQ-9) has 9 items and was developed by Spitzer, Williams, Kroenke and colleagues in year 2001 (25). Scoring is by summation of the boxes on PHQ-9 questionnaire (For every Not at all = 0; Several days = 1; More than half the days $=2$; Nearly every day = 3). Interpretation of Total Score: Depression Severity 1) Minimal depression (1-4), 2) Mild depression (5-9), 3) Moderate depression (10-14), 4) Moderately severe depression (1519), 5) Severe depression (20-27). It too has been used widely to screen for depressive symptoms globally and widely validated in different patient populations in SSA. PHQ-9 scores $>10$ had a sensitivity of $88 \%$ and a specificity of $88 \%$ for Major Depressive Disorder. The diagnostic validity of the 9 -item PHQ- 9 was established in studies involving 8 primary care and 7 obstetrical clinics. 
In South Africa it was found to be reliable for criteria-based clinical depression disorders diagnosis, it is also good for severity check and perfect for clinical and research use. The study conducted a validation study of an interviewer-administered brief screening tool for depression, in a high HIV burden, low literacy

PHC population in Johannesburg, South Africa (26). The results provide insight on how we can screen for and prioritize often overlooked and highly prevalent depressive symptoms in low-resource PHC settings in sub-Saharan Africa. This study provides a framework for implementing depression screening programs in resource-scarce sub-Saharan African contexts and establishes the PHQ-9 as a useful screening instrument in these settings (27).

\section{Data collection Procedure}

It encourages an in-depth exploration of particular concepts, processes and patterns of interpretation. To achieve this, the process of cognitive testing analyses the question-response process in four stages:

i. Comprehension: This is a stage where the respondent interprets the question. Difficulty at this stage may reflect unfamiliar or complex expressions or words or unclear concepts.

ii. Retrieval: At this point respondent searches memory for answer. Recall difficulty can be a challenge at this stage.

iii. Judgment: The respondent estimate response. Difficulty in estimating response may reflect bias or sensitive question.

iv. Response: The respondent provides answer in the format requested. The answer provided may expose issues of incomplete response options.

The aim is to understand how each participant interprets the assessment items and selects responses. Due to the personal nature of cognitive interview, in that it involves asking the respondent what they are thinking or feeling when answering a question, it will therefore, be made clear to respondents when they have volunteered for a cognitive interview what it involves in order to maximise cooperation and yield from the process. The research team will also attend to any issues with sensitivity of the questions or poor comprehension of the domains to be assessed.

Cognitive interviewing as a method explores how the researchers' and participants' understanding of the constructs intersect. It allows an opportunity to scan the participants' perceptions, fund of knowledge, comprehension and at the same time gives unique information on the acceptability of the ideas tested in a tool. It allows cross-cultural, developmental (as we deal with adolescents) validation of depression constructs.

The participants were taken through a briefing on the objective of the interview and their written and oral consent taken to record their experiences. Participants were assured that they could withdraw when they felt like discontinuing and were assured of assistance if screened with high depressive symptoms. Referrals were made to the psychiatric nursing officer at the health facility and individual follow up done by the clinical psychologist research assistant.

The protocol was developed by the first author and the two research assistants MK and VN interviewed and collated data on the tools. A structured worksheet was available for research assistants to transcribe the participants' response verbatim. These notes were translated by the interviewing research assistants. The study team reviewed cognitive interview transcripts, discussed and addressed items requiring revision.

\section{Data analysis}

At first all the scores were compiled for a brief summary score report and reliability analysis for the two scales and two translated versions carried out. The cognitive interviewing was sequenced in a four domains assessment which was collated by the study team. Each participant was offered both tools but they could choose, English or Kiswahili version and for each item they were asked what the item a) meant and how well they understood the question b) what did they think it asked about and c) what their own response was; including being administered the questionnaire to map their depression experiences and severity. This data was descriptively presented to reflect participants' understanding of the tool items. Finally, a thematic analysis informed qualitative synthesis of the core findings of these interviews was carried out to present gaps in our understanding of depression in young adolescent girls, their own life experiences and clinical signs and symptoms that depression and other mental health interventions need to target.

\section{Results}

The key findings are broken down into three sections. First, is the presentation of cognitive interviews along the four domains of comprehension, judgement, retrieval and experiential response to items described earlier and along with it we present their summary scores and a descriptive report on item level reliability analysis computed through Cronbach alpha. Finally, we offer some qualitative analyses of what depression meant for our sample and the kinds of associations to depression that young girls brought out in relation to the pregnancy or motherhood experience. We interviewed thirty-two female participants between ages 14-18 years. Half of the participants were pregnant, and the other half were postpartum and twenty-one of these participants were living on their own or with parent (in the absence of a partner) and the remaining were married. See table 1 for sociodemographic characteristics of the participants and table 2 for depression cut off scores for both tools.

\section{Cognitive interviews summary}

We had eight participants interviewed using EPDS Kiswahili and another nine using EPDS English version. Nine participants were interviewed using PHQ-9 English and six using PHQ-9 Kiswahili version. As described in the methods section, the participants were scored for their ability in comprehension, retrieval, judgement and response quality. We were also scoring these participants on the questionnaire using the formal scoring. See table 3 that looks at cognitive interview rating for PHQ-9 and EPDS English and Kiswahili versions.

On PHQ-9 English interviews ( $\mathrm{n}=9$ ) we found that our participants had a difficult time following the item 1, 'little interest or pleasure in doing things', with explanations such as, 'you could want to do something but you don't have the support needed, When one lives in a mistreated environment'. On item 2, feeling

Page 4/17 
down depressed and hopeless', one of our participants doesn't understand the item, she says 'doesn't comprehend it all "feeling down" is hard'. On item 4 'feeling tired or having little energy', most of the participants understood the item however there were odd one or two responses where there was some unclarity around comprehension. Responses such as 'she feels lazy/feeling "maybe I am sick" she forces self to go to work'leave us wondering whether this 15 year old with 7-month pregnancy is able to grasp the item fully. Item 5 was well understood by all. On item 6 'feeling bad about yourself- or that you are a failure or have let yourself or your family down' some responses like 'blames oneself, feels she is a let-down' does convey that there is an overwhelming sense of resonance with the theme that the item conveys. On item 7 around 'trouble concentrating on things, such as reading the newspaper or watching television', there were at least two participants who had issues with comprehending the question with responses such as 'not being able to listen to news'or another 15 years old saying that she didn't get the question. On item 8 , 'moving or speaking so slowly that other people could have noticed. Or the opposite-being so fidgety or restless that you have been moving around a lot more than usual' one of our 18 years old mother of one-month old child responded 'when unhappy her voice goes down', another 6 months pregnant 16 years old said that 'If you change hormones to walk or talk with say bitterness, anger'. On item 9 about 'thoughts that you would be better off dead, or of hurting yourself', almost everyone had a good sense of what it meant.

On PHQ-9 Kiswahili cognitive interviews $(n=6)$, we found that two of our participants had a hard time following the question. With one 18 years old with a 10month old baby saying, 'I have not understood the question' and another one having difficulties understanding the response items. On item 2 , a 17 years old pregnant participant does not follow the item despite repeating and another participant 18 years old mother responds, 'if you are going through a lot of trouble'. Item 3 was well-understood by all our participants. On item 4, one of our 18 years old young mother's feedback was that 'you feel tired after doing a lot of work' and such responses can be perplexing as one may be offering one's lived experience than the understanding of the question per sae. Another 17 years old 6-months pregnant participant felt that she didn't understand the question and needed it to be explained. On item 5 one of our 17 years old participants shared her understanding that 'maybe if you feel like eating' which again did not capture the actual meaning of the item. One of our 17 years old 7-months pregnant participant had problems following the item 6 . Another 17 years old 6 months and 18 years old young mother responded to the item as 'maybe your parent asks you for something and you don't have; you feel bad', and 'for example parents ask for money at the end of the month but you don't have,' another 14 years old 10-months pregnant adolescent said 'means that you feel bad and not happy about your family and you think of bad things'. On item 7, one of our 16 years old 7-months pregnant adolescent responded that 'paying attention while doing something or reading' and the 18 years old adolescent mother said, 'it's like reading a magazine reduces stress'. A 17 years old participant wanted this item to be explained again. Another 18 years old with one-year old baby made an interesting comment 'I don't have a TV and also don't read newspapers.' On item 9, one of our 16 years old 7-months pregnant participant's interpretation was 'people realizing that you have changed a lot. Looking as if you are absent-minded'. One of our 18 years old young mother didn't understand the item while another 18 years old young mother said that 'I walk slowly because walking fast can make you get hit by a motorcycle'. On item 9, one 17 years old 6-months pregnant adolescent said that 'I have understood but I don't know how to explain' and other than that all participants understood the meaning of the item well.

On EPDS English version ( $n=9)$, on item 1, 'I have been able to laugh and see the funny side of things', one of our 18 years old with 2 months pregnancy, responded 'I have been able to laugh and see the funny side of things'though another 16 years old 5-months pregnant adolescent did not follow the item despite being reminded a number of times. One 14 years old 6-months pregnant adolescent responded "'seeing the funny side of things" is difficult to understand' and another 14 years old responded 'I can laugh but sometimes I am angry. On item 2 'I have looked forward with enjoyment to things.' Our 14 years and 6-months pregnant participant says, 'if I can see and enjoy and the 16 years old 5-months pregnant participant does not understand the question. Another 14 years old 6-months pregnant says ' waiting for the pregnancy with joy' and another 15 years old with 10-months old baby says, 'due to baby responsibility she has to work hard and have hope'. On item 3, 'I have blamed myself unnecessarily when things went wrong', one of our participants says, 'I hated myself', another 16 years old 5-months pregnant participant does not understand the question even after multiple repetitions. On item 4, 'I have been anxious or worried for no reason', one of our 18 years old participant who is mother of a two-year old says, 'when thinking of something that will hurt you but others see success,' and our 16 years old 5-months pregnant and another 14 years old 6-months pregnant participants 'did not know the meaning of "anxious"'. On item 5, 'I have felt scared or panicky for no very good reason,' our participants interpreted it as, 'you might want to do something but fear of how people will react; yet others see that you are able to succeed in doing it'.

On item 6, 'things have been getting on top of me', our 14 years 6-months pregnant adolescent interpreted as, 'things can come at my time', while 16 years old 5 -months pregnant adolescent thought it was a difficult question to follow, another 14 years old 6-months pregnant participant found it difficult as she explained it as, 'things that are continuing to happen to me'. Another 15 years 10-months pregnant participant explained it as, 'if she had a partner, she would be able to carry the big load rather than alone'. On item 7 'I have been so unhappy that I have had difficulty sleeping', one of our 17 years old 2-months pregnant participant interpreted this as, 'if she has a problem it means that she has to step up' and two other participants 16 years old 5-months pregnant and 14 years old 6-months pregnant did not understand the question despite being repeated. On item 8, 'I have felt sad or miserable', two of our 18 years old 2months pregnant and 14 years old 6-months pregnant participants were not able to understand the word "miserable." Another 17 years old mother of 2months old baby associated it with 'being helpless' and two participants, one 14 years old 6-months pregnant and another 16 years old 5-months pregnant interpreting it as, 'I can lack happiness'. On item 9, 'I have been so unhappy that I have been crying', one 16 years young mother said 'she reports crying at first but now she has accepted', and another 14 years old 6-months pregnant participant interpreted as, 'if I can be unhappy and cry,' and another 16 years old 5months pregnant participant said she understood but didn't respond. On item 10, 'the thought of harming myself has occurred to me', most participants understood it however our 14 years old 6-months pregnant participant said 'that one is difficult', another 16 years old 5-months pregnant participant understood but did not respond.

On EPDS Kiswahili version ( $\mathrm{n}=8$ ), on item 1, one of our 16 years old 8-months pregnant participant said, 'if you have laughed because you have seen things', one 17 years 2-months pregnant participant did not understand. Another 15 years young mother of one also did not understand the item. On item 2, one of our 17years old mother of 8-months old child also did not follow the question and another 17 years old 2-months pregnant participant also did not follow the question. Another 15 years old young mother said doesn't understand the meaning of "I have looked forward" and the 18 years old 8-months pregnant said, 'it 
means if I have looked forward to things with enjoyment'. On item 3, one 16 years old 8-months pregnant interpreted it as, 'if you were not used to blaming yourself', another 17 years old 3-months pregnant participant did not follow the question and a 15 years old young mother said, 'if you insult your parents'. On item 4, our 16 years old 8-months pregnant participant said, 'if you never liked being worried', another 17 years old 3-months pregnant participant did not understand. On item 5, our 16 years 8-months pregnant participant said, 'In the past you were not scared or anxious', however others did understand the item well. On item 6, one of our 16 years old 8-months pregnant participant said, 'in the past you never used to face issues but now you are facing them', and another 17 years old mother of 8-months old said, 'it means failure to understand well'. Another 17 years old 3-months pregnant participant did not understand the item. On item 7, one participant a young 15 years old mother of one-year old child said, 'if your loved-one dies'. On item 10 our 15 years old mother of one did not follow the question.

Some of our participants had a hard time following the questions especially on the Kiswahili versions of the tools (which they preferred over English). Often times they would say that the question is hard to follow. For example, when asked if the participant experienced same levels of enjoyment in things she used to like doing before, one of our 17 years old 2-months pregnant participant said 'that question is hard', she repeated this for couple of other questions. Another 17 years old 3-months pregnant participant when asked if she blamed myself unnecessarily when things went wrong from EPDS said that she didn't understand the question and that it was hard.

Psychometric analysis of the two tools with two translated versions

Tables 4 and 5 offer reliability analysis of the two tools. We can see that for PHQ -9 combined the overall Cronbach's a for internal reliability is 0.56 and for EPDS is 0.76 . On EPDS, 5 participants had a score of over 14 indicating moderate depression, on PHQ-9, 6 participants who scored under moderate depression category and 5 participants who scored 15-19 moderate severe depression. Our sample size is certainly limited and therefore it is imperative to interpret these findings cautiously. Mean score of EPDS English version is $12.89(\mathrm{SD}=5.71)$ and Kiswahili version is $9(\mathrm{SD}=6.55)$ and mean score on $\mathrm{PHQ}-9$ English version is $12.44(\mathrm{SD}=4.69)$ and Kiswahili PHQ-9 version is $11.33(\mathrm{SD}=4.08)$.

\section{Thematic analysis of the participant interviews}

The interviews were at another level very poignant and painful reminder of how deeply affected these adolescents were in some ways by the pregnancy and unintended/ unplanned motherhood.

Manifestations of depression

Our participants shared through these interviews several feelings and experiences associated with being, down dejected and hopeless. Almost always there were adverse family experiences and lack of provision for their basic needs that contributed to feeling dejected.

Yeah you cry and ask yourself why did it have to happen to- why is it only me that was supposed to be in this situation; so I ask myself several questions I even lose several things in life, education. Thoughts of harming myself have come to me several times. (18 years old with 2 months old baby).

You can just be in deep thoughts thinking a lot of things, maybe you are stressed and you are unable to fall asleep.... (18 years old mother with 8 months old baby, PHQ- score of 12)

The second participant often contemplates suicide when her father is rough with her and the mother is pressing her to stay with the baby rather than take up a job and fend for herself and family.

When you wake up feeling that way and the parents are around, they start quarrelling saying that you are a girl and you don't want to work you have left all the house chores for other siblings. At times feel very tired and hungry - sometimes there is food sometimes there isn't. I normally feel that I have let them down because they expected me to at least to raise their living standard in future but instead I got pregnant. (16 years old with a 4 months old baby and a PHQ-9 score of 18)

Depression is lacking peace... you feel bad about your body or it's like you have let yourself or your family down. ... I was in school when I got this child so my mother just wasted all her money taking me to school. I just feel bad because right now I am at home and all my sisters are at school continuing with their studies so I tell myself if I wouldn't be in this situation I would be in school. (18 years old mother of 2 months old infant, PHQ-9 score of 13).

Similar sentiments around being disenfranchised were shared by another participant

That feeling you get when wronged, you don't want to talk to anybody and just want to be left alone I do feel bad. At times I even contemplate suicide. (16 years old mother of 4 months old infant, scored 18 on PHQ-9)

Absence of social support and loneliness was also alluded to by a participant.

Because the child's dad does not support me and I am suffering alone. I have contemplated suicide. I usually sit down and correct myself; I talk to myself and say that this is not the best thing to do. There are many challenges.....lacking a person to talk to sometimes (17 years old mother with EPDS score of 19).

These experiences of not finding support are also complex and also worthy of further exploration as they hinge on several challenging experiences of being left alone, not having anyone to talk to, going hungry, lacking provision of basic needs etc. The descriptions make it seem that the experience of unintended and unplanned pregnancy is a significant jolt for more or less every adolescent.

Acceptance of pregnancy

Page 6/17 
While accepting the pregnancy and receiving support from the parents to help deliver the baby, the adolescent feels that there will be significant trade-offs between returning to school, finding job and caring for the baby. Even though the pregnancy is accepted helplessly as a fact of life, the implications of longterm responsibility and support that an adolescent has to vouch for, is something that young girls seem to struggle with tremendously.

Support and stresses around adolescent's caregivers especially mother

It means the way I am and the way I was, the level of happiness before and now, if I am just happy just the way I used to be, I was very happy when I was pregnant and up to now it is not gone especially when I see my baby, it makes me feel happy because I know even though I am raising the baby alone I know one day she/he will help me (17 years old with 10 months old infant, score of 13 EPDS)

'Yes. Because sometimes I just ask myself 'now where is my life heading to?', where I am today and where I will be, I sometimes try to give myself hope and then I feel that maybe I am giving myself hope yet I will not reach where I want to be.... It is like when you over-think and feel like life has become difficult and you cannot take it anymore so you feel like the only solution is to take your life to avoid troubles, but again when you think about your baby you feel that 'who will I leave him with?' and you also don't want to leave that burden to your mother, because you will also leave her with stress and she can even die.(17 years old 10 months old)

problem of I mean many troubles whenever you are stressed it leads somebody to lose whatever -there is something you just lose; it is like you become insane. You lose a lot - cannot go to school... because you might find that even in school people are laughing at you, you regret so it makes you feel like you are stigmatized. My self-blame comes from due to peer pressure about others and my friends they led me into a wrong way then I fall out [Inaudible] I used to blame myself....now I have returned to school (18 years old mother with 2 years child, 16 score on EPDS)

it reached a point when my mother, you know my mother left us when we were still very young. When I was three years old when she died, so we were left with my grandmother, then my father was arrested, so we went through a lot, my grandmother's leg broke, so our grandfather took the initiative of feeding us, clothing us. Taking us to school; either we go or we don't because we have been sent away due to lack of fees and we are just at home. It reaches a point I could start to cry and say [Inaudible] 'why has mum left us?' Our father lived in prison about four years (18 years old mother of 8 months baby, PHQ 9 score of 12).

\section{Demanding multitasking and early adultification}

Stress at home yeah; you may have gone to school then she tells you, you know she remains back; she doesn't go to work then you tell her 'mum since you are not going to work can you stay with the child for me for a while,' then she will refuse, even if it is Sunday. I may come back from school in the evening then you find that everything is waiting for you there so (18 years old with 2 years old baby, 16 on EPDS)

Maybe you had something urgent that you wanted to do but you have not done it because maybe you have a lot of work to do, so you will be forced to be more faster to be able to handle other tasks, or maybe you have a lot of stress (16 years old with 4 months baby, 18 on PHQ)

\section{Discussion}

The paper has adopted a two-pronged approach of introducing findings of cognitive interviews from the two sets of tools, briefly reviewing their psychometric properties using Kiswahili and English language versions and developing a thematic analysis on the experiences around various questionnaire items. We were hoping to summarize the life experiences of our participants as well as experience and process of conducting a cognitive interview exercise through this approach.

Psychometrically, we think that EPDS is a better tool than PHQ-9 for our adolescent sample for two reasons- one, the latter is more congruent with the peripartum context and second, the questions are organized more sensitively. The Kiswahili translation was significantly better than the PHQ-9 translation. On both tools we can see several items where the item reliability scores were poor and can see that PHQ-9 had many more items with poorer alphas. We think that the factor structure of the tools may be different for pregnant and parenting adolescents than the adult samples. This warrants further analysis that is currently outside the scope of this paper and we acknowledge that our sample is limited to make clear conclusions.

In Kenya Cognitive testing of the PHQ-9 has been conducted for depression screening among pregnant and postpartum women (28). Results showed that most participants preferred to answer the PHQ-9 in Kiswahili ( $N=15 ; 52 \%)$. Among the 20 interview participants, 12 ( $60 \%)$ had scores $\geq 5$, indicating depressive symptoms. Overall, participants found the scale acceptable as an interviewer-administered tool. Participants reported few problems related to comprehension but had difficulty answering items not relevant to their lives (e.g., "watching television") and double-barreled items (e.g., "poor appetite or overeating"). They were hesitant to endorse items related to "duties as a wife and mother" and suicidal ideation. Most participants had difficulty distinguishing between response options of "several days" and "more than half the days".

Cognitive interview findings do make us feel that the distillation of actual experiences and meaning of those states of mind and bodily reactions may not completely fit with each other. However, at the same time separating the two would be difficult. Both tools were better received for most parts when delivered in English as young people felt more comfortable in English. Very chaste Kiswahili may no more be used in urban informal settlements where 'sheng' a hybrid of Kiswahili, English and colloquial dialects are used.

It is sometimes hard to be an objective witness of one's distress while undergoing in that moment. This is something that trauma researchers know well in their work around testimonies of trauma. At times these cognitive interviews were akin to testimonies of pain and sadness of life circumstances and adverse choices one has made. In almost all statements that the participants offered their understanding and experience, we noted the overwhelming distress, 
helplessness, sadness and sense of isolation they went through. There was early adultification and end of school education, very painful reality of looking after a new being and not having time or resources to become a full time carer. The interview transcripts were a testament to how stoic adolescents were around particular questions of whether they have let others down, feeling hopeless and that their life is not worth living. Their pauses, delayed responses and at times asking for the question to the repeated again felt as though these questionnaire items were like frozen metaphors for their state of mind and existence.

We found interesting themes like participants wanting more attuned care and support from their mothers and at the same time knew how hard things were going to become for the adolescent's mother. This duality was very striking. The interpersonal web of challenges around adolescent pregnancy and motherhood is quite significant. The missing supportive male caregiver and absence of a wiling and responsible partner/boyfriend cannot be underscored. The participants also appeared to become more aware of their state of mind as the questionnaire items were presented. In a context where mental health is poorly understood, these questionnaires become an odd encounter of coming face to face with all cognitive processes and emotions that must underlie adolescent experience of encountering unplanned motherhood.

\section{Limitations}

We did not administer the four sets of tools on all participants. It would have been difficult from a design as well as measurement point of view repeating similar kinds of questions on participants raising even ethical issues of exposing them to further duress.

\section{Conclusion}

For pregnant and parenting adolescents in low resource settings or in LMICs it would be important to consider using the self-administered depression or mental health questionnaires carefully. It may be important to have group assessments facilitated by an experienced social worker, health worker with training in mental health or by a psychologist. We need to make response items of these public mental health tools more responsive to adolescent and less literate populations. Kenyan pregnant adolescents and adolescent mothers demonstrate significant mental distress and depressive symptoms however the precise assessment of the extent of their depressive symptoms cannot be reliably ascertained given the issues that have been presented in this paper.

\section{Declarations}

Ethics approval and consent to participate: the study which has been approved by Kenyatta National Hospital/University of Nairobi ethical review committee (approval no. P694/09/2018). The study received approval from Nairobi county health directorate (approval no. CMO/NRB/OPR/VOL1/2019/04) and approval from National Commission for Science, Technology and Innovation (NACOSTI/P/19/77705/28063). The written informed consent to participate was sought from all study participants.

Consent for publication: all study participants would be asked for their written consent to publish the findings of this work. The key study participants and their family member data would be anonymized, and the personal information would be kept confidential

Availability of data and material: NIMH funded research requires the data to be made available in publicly available. The data from this study would be made available on repositories such as Clinicaltrials.gov, RDoCdb, FIC webpage. All the personal information would be de-identified, and the data put on excel sheets for research use. Some interview transcripts would be kept by the researcher and may be shared on reasonable request.

Competing interests: the authors do declare that they do not have any competing interests

Funding: Research reported in this publication was supported by the Fogarty International Center of the National Institutes of Health under Award Number K43TW010716. The content is solely the responsibility of the authors and does not necessarily represent the official views of the National Institutes of Health. The first author was funded by Fogarty Foundation K43 grant (2018-2023) entitled 'implementing mental health interventions for pregnant adolescents in primary care LMIC settings' under which this study was undertaken.

Authors' contributions: MK developed the paper, MK and VN conducted the interviews along with MK, all authors contributed to the draft and made edits and approved the MS. All authors have read and approved the manuscript.

Acknowledgements: Our study participants for their time, Sahiba Turgesen for her editorial assistance and Nairobi county and the two-health facilities staff for their support and guidance.

\section{Abbreviations}

LMICs - Lower-and-Middle-Income Countries

PHQ-9- Patient Health Questionnaire- 9

EPDS- Edinburgh Postnatal Depression Inventory

$\mathrm{Cl}$ - Cognitive Interviewing

\section{References}


1. James SL, Abate D, Abate KH, Abay SM, Abbafati C, Abbasi N, et al. Global, regional, and national incidence, prevalence, and years lived with disability for 354 diseases and injuries for 195 countries and territories, 1990-2017: a systematic analysis for the Global Burden of Disease Study 2017. Lancet [Internet]. 2018 Nov;392(10159):1789-858. Available from: https://linkinghub.elsevier.com/retrieve/pii/S0140673618322797.

2. Falicov CJ. Culture, society and gender in depression. In: Journal of Family Therapy. 2003. p. 371-87.

3. Engel GL. The clinical application of the biopsychosocial model. Am J Psychiatry [Internet]. 1980 May;137(5):535-44. Available from: http://www.ncbi.nlm.nih.gov/pubmed/7369396.

4. Kohrt BA, Mendenhall E, Brown PJ. How anthropological theory and methods can advance global mental health. Vol. 3, The Lancet Psychiatry. 2016. p. 396-8.

5. Marsella AJ. Thoughts on cross-cultural studies on the epidemiology of depression. Cult Med Psychiatry. 1978;2(4):343-57.

6. Kleinman A, Benson P. Anthropology in the clinic: The problem of cultural competency and how to fix it. PLoS Medicine. 2006;Vol. 3:1673-6.

7. Cassano P, Fava M. Depression and public health: An overview. In: Journal of Psychosomatic Research. 2002. p. 849-57.

8. Jacob KS. Depression. A major public health problem in need of a multi-sectoral response. Indian J Med Res. 2012;Vol. 136:537-9.

9. World Health Organization. mhGAP Intervention Guide Mental Health Gap Action Programme Version 2.0 for mental, neurological and substance use disorders in non-specialized health settings. World Heal Organ. 2016;1-173.

10. WHO. The Global Burden of Disease. 2004 update. Update [Internet]. 2008 [cited 2020 May 3];2010:146. Available from:

http://www.who.int/healthinfo/global_burden_disease/2004_report_update/en/index.html.

11. 10.1186/s12888-018-1706-y

Osok J, Kigamwa P, Stoep A, Vander, Huang K-Y, Kumar M. Depression and its psychosocial risk factors in pregnant Kenyan adolescents: a cross-sectional study in a community health Centre of Nairobi. BMC Psychiatry [Internet]. 2018 Dec 18;18(1):136. Available from:

https://bmcpsychiatry.biomedcentral.com/articles/10.1186/s12888-018-1706-y.

12. Ongeri L, Wanga V, Otieno P, Mbui J, Juma E, Stoep A, Vander, et al. Demographic, psychosocial and clinical factors associated with postpartum depression in Kenyan women. BMC Psychiatry. 2018;18(1):1-9.

13. $10.1186 / \mathrm{s} 12978-015-0092-x$

Biratu A, Haile D. Prevalence of antenatal depression and associated factors among pregnant women in Addis Ababa, Ethiopia: A cross-sectional study. Reprod Health [Internet]. 2015;12(1):1-8. Available from: http://dx.doi.org/10.1186/s12978-015-0092-x.

14. Dibaba Y, Fantahun M, Hindin MJ. The association of unwanted pregnancy and social support with depressive symptoms in pregnancy: Evidence from rural Southwestern Ethiopia. BMC Pregnancy Childbirth. 2013;13:1-8.

15. Govender D, Naidoo S, Taylor M. Antenatal and Postpartum Depression: Prevalence and Associated Risk Factors among Adolescents' in KwaZulu-Natal, South Africa. Depress Res Treat. 2020;2020.

16. /doi/10.1177/0269216315608348

Schildmann EK, Groeneveld El, Denzel J, Brown A, Bernhardt F, Bailey K, et al. Discovering the hidden benefits of cognitive interviewing in two languages: The first phase of a validation study of the Integrated Palliative care Outcome Scale. Palliat Med [Internet]. 2016 Jun 28;30(6):599-610. Available from: http://journals.sagepub.com/doi/10.1177/0269216315608348.

17. $10.1186 / \mathrm{s} 12913-018-2867-6$

Murphy M, Hollinghurst S, Salisbury C. Qualitative assessment of the primary care outcomes questionnaire: a cognitive interview study. BMC Health Serv Res [Internet]. 2018 Dec 1;18(1):79. Available from: https://bmchealthservres.biomedcentral.com/articles/10.1186/s12913-018-2867-6.

18. Peterson $\mathrm{CH}$, Peterson NA, Powell KG. Cognitive interviewing for item development: Validity evidence based on content and response processes. Meas Eval Couns Dev. 2017;50(4):217-23.

19. Cox JL, Holden JM, Sagovsky R. Detection of Postnatal Depression: Development of the 10-item Edinburgh Postnatal Depression scale. Br J Psychiatry. 1987;150(JUNE):782-6.

20. McCabe-Beane JE, Segre LS, Perkhounkova Y, Stuart S, O'Hara MW. The identification of severity ranges for the Edinburgh Postnatal Depression Scale. J Reprod Infant Psychol. 2016;34(3):293-303.

21. Ing H, Fellmeth G, White J, Stein A, Simpson JA, McGready R. Validation of the Edinburgh Postnatal Depression Scale (EPDS) on the Thai-Myanmar border. Trop Doct. 2017;47(4):339-47.

22. $10.1186 / \mathrm{s} 12884-019-2594-y$

Shitu S, Geda B, Dheresa M. Postpartum depression and associated factors among mothers who gave birth in the last twelve months in Ankesha district, Awi zone, North West Ethiopia. BMC Pregnancy Childbirth [Internet]. 2019 Dec 21;19(1):435. Available from:

https://bmcpregnancychildbirth.biomedcentral.com/articles/10.1186/s12884-019-2594-y.

23. $10.1186 / \mathrm{s} 12884-018-1948-1$

Khalifa DS, Glavin K, Bjertness E, Lien L. Course of depression symptoms between 3 and 8 months after delivery using two screening tools (EPDS and HSCL-10) on a sample of Sudanese women in Khartoum state. BMC Pregnancy Childbirth [Internet]. 2018 Dec 8;18(1):324. Available from:

https://bmcpregnancychildbirth.biomedcentral.com/articles/10.1186/s12884-018-1948-1.

24. Linnet Ongeri MK. Translation of EPDS Questionnaire into iswahili: Understanding the Cross-Cultural and Translation Issues in Mental Health Research. J Pregnancy Child Heal [Internet]. 2015;02(01):1-10. Available from: http://www.omicsgroup.org/journals/translation-of-epds-questionnaire-into-kiswahiliunderstanding-the-crosscultural-and-translation-issues-in-mental-health-research-jpch.1000134.php?aid=37280.

25. Kroenke K, Spitzer RL, Williams JBW. The PHQ-9: Validity of a brief depression severity measure. J Gen Intern Med. 2001;16(9):606-13.

Page 9/17 
26. Cholera R, Gaynes BN, Pence BW, Bassett J, Qangule N, Macphail C, et al. Validity of the patient health questionnaire-9 to screen for depression in a highHIV burden primary healthcare clinic in Johannesburg, South Africa. J Affect Disord [Internet]. 2014 Oct;167:160-6. Available from: https://linkinghub.elsevier.com/retrieve/pii/S0165032714003644.

27. Gelaye B, Rondon MB, Araya R, Williams MA. Epidemiology of maternal depression, risk factors, and child outcomes in low-income and middle-income countries. The Lancet Psychiatry [Internet]. 2016 Oct;3(10):973-82. Available from: https://linkinghub.elsevier.com/retrieve/pii/S221503661630284X.

28. Velloza J, Njoroge J, Ngure K, Thuo N, Kiptinness C, Momanyi R, et al. Cognitive testing of the PHQ-9 for depression screening among pregnant and postpartum women in Kenya. BMC Psychiatry. 2020;20(1).

\section{Tables}

Table 1. Sample Characteristics for Full- and Subsample

\begin{tabular}{|c|c|c|c|c|c|c|}
\hline \multirow{4}{*}{ Variable } & \multirow{4}{*}{ Category } & \multirow{2}{*}{$\begin{array}{l}\text { Full Sample } \\
\text { Total Sample }\end{array}$} & \multicolumn{2}{|c|}{ By Assessment Tool } & \multicolumn{2}{|c|}{ By Condition } \\
\hline & & & EPDS & PHQ-9 & Pregnant & Postpartum \\
\hline & & $\mathrm{N}=32$ & $\mathrm{~N}=17$ & $N=15$ & $\mathrm{~N}=16$ & $\mathrm{~N}=16$ \\
\hline & & $(100 \%)$ & (53.1\%) & $(46.9 \%)$ & $(50.0 \%)$ & $(50.0 \%)$ \\
\hline & & $\mathrm{N}(\%)$ & $\mathrm{N}(\%)$ & $\mathrm{N}(\%)$ & $\mathrm{N}(\%)$ & $\mathrm{N}(\%)$ \\
\hline \multirow[t]{5}{*}{ Age } & 14 & $4(12.5 \%)$ & $3(17.6 \%)$ & $1(6.7 \%)$ & $1(6.3 \%)$ & $3(18.8 \%)$ \\
\hline & 15 & $4(12.5 \%)$ & $2(11.8 \%)$ & $2(13.3 \%)$ & $1(6.3 \%)$ & $3(18.8 \%)$ \\
\hline & 16 & $7(21.9 \%)$ & $3(17.6 \%)$ & $4(26.7 \%)$ & $6(37.5 \%)$ & $1(6.3 \%)$ \\
\hline & 17 & $8(25.0 \%)$ & $4(23.5 \%)$ & $4(26.7 \%)$ & $6(37.5 \%)$ & $2(12.5 \%)$ \\
\hline & 18 & $9(28.1 \%)$ & $5(29.4 \%)$ & $4(26.7 \%)$ & $2(12.5 \%)$ & $7(43.8 \%)$ \\
\hline \multirow[t]{2}{*}{ Marital status } & Single & $21(65.6 \%)$ & $10(58.8 \%)$ & $11(73.3 \%)$ & $8(50.0 \%)$ & $13(81.3 \%)$ \\
\hline & Married & $11(34.4 \%)$ & $7(41.2 \%)$ & $4(26.7 \%)$ & $8(50.0 \%)$ & $3(18.8 \%)$ \\
\hline \multirow[t]{2}{*}{ Condition } & Pregnant & $16(50.0 \%)$ & $9(52.9 \%)$ & $7(46.7 \%)$ & & \\
\hline & Postpartum & $16(50.0 \%)$ & $8(47.1 \%)$ & $8(53.3 \%)$ & & \\
\hline
\end{tabular}

Table 2 Depression severity

\begin{tabular}{|lll|}
\hline $\begin{array}{l}\text { Depression Level } \\
\text { (EPDS) }\end{array}$ & $\begin{array}{l}\text { Frequency } \\
\mathbf{( N = 1 7 )}\end{array}$ & $\begin{array}{l}\text { Percentage } \\
\mathbf{( \% )}\end{array}$ \\
\hline Minimal Depression (=<8) & 5 & 29.4 \\
\hline Mild Depression (9-11) & 7 & 41.2 \\
\hline Moderate Depression (12-13) & 4 & 23.5 \\
\hline Severe Depression (>=14) & 1 & 5.9 \\
\hline Depression level (PHQ-9) & $\mathbf{N}=\mathbf{1 5}$ & $\%$ \\
\hline Mild Depression (5-9) & 4 & 26.7 \\
\hline Moderate Depression (10-14) & 6 & 40 \\
\hline Moderate Severe depression (15-19) & 5 & 33.3 \\
\hline
\end{tabular}

Table 3 Cognitive interview rating sheets for PHQ-9 English and Kiswahili, EPDS English and Kiswahili 


\begin{tabular}{|c|c|c|c|c|c|c|c|c|}
\hline & Participant & Item 1: & Item 2: & Item 3 & Item 4: & Item 5: & Item 6: & Item 7: \\
\hline $\begin{array}{l}\text { PHQ9- } \\
\text { ENGLISHCode/ }\end{array}$ & $\begin{array}{l}\text { gestational } \\
\text { status }\end{array}$ & $\begin{array}{l}\text { Little } \\
\text { interest or } \\
\text { pleasure in } \\
\text { doing things }\end{array}$ & $\begin{array}{l}\text { Feeling } \\
\text { down, } \\
\text { depressed, or } \\
\text { hopeless }\end{array}$ & $\begin{array}{l}\text { Trouble falling or } \\
\text { staying asleep, or } \\
\text { sleeping too } \\
\text { much }\end{array}$ & $\begin{array}{l}\text { Feeling } \\
\text { tired or } \\
\text { having little } \\
\text { energy }\end{array}$ & $\begin{array}{l}\text { Poor appetite or } \\
\text { overeating }\end{array}$ & $\begin{array}{l}\text { Feeling bad } \\
\text { about yourself- } \\
\text { or that you are } \\
\text { a failure or } \\
\text { have let } \\
\text { yourself or your } \\
\text { family down }\end{array}$ & $\begin{array}{l}\text { Trouble } \\
\text { concentrating } \\
\text { on things, sucl } \\
\text { as reading the } \\
\text { newspaper or } \\
\text { watching } \\
\text { television }\end{array}$ \\
\hline
\end{tabular}

Overall score

and severity

Response

set:

Participant responses and response options, Feedback

\begin{tabular}{|c|c|c|c|c|c|c|c|c|c|c|c|c|c|c|c|c|c|c|c|c|c|c|}
\hline \multirow[t]{3}{*}{$\begin{array}{l}\text { KII AD } 01 \text { KR } \\
\text { 18-severely } \\
\text { moderate }\end{array}$} & $\begin{array}{l}16 \text { Yrs } \\
\text { Child } 5 \\
\text { months }\end{array}$ & \multicolumn{3}{|c|}{$\begin{array}{l}\text { You could } \\
\text { want to do } \\
\text { something } \\
\text { but you } \\
\text { don't have } \\
\text { the support } \\
\text { needed }\end{array}$} & \multicolumn{3}{|c|}{$\begin{array}{l}\text { It means } \\
\text { someone } \\
\text { has annoyed } \\
\text { you and you } \\
\text { want to be } \\
\text { all alone }\end{array}$} & \multicolumn{3}{|c|}{$\begin{array}{l}\text { You can sleep } \\
\text { too much and } \\
\text { stress a lot or } \\
\text { sleep to death }\end{array}$} & \multicolumn{3}{|c|}{$\begin{array}{l}\text { You could } \\
\text { have woke } \\
\text { up tired } \\
\text { with no } \\
\text { moods to } \\
\text { do anything }\end{array}$} & \multicolumn{3}{|c|}{$\begin{array}{l}\text { When } \\
\text { breastfeeding } \\
\text { you need to eat } \\
\text { well to feed the } \\
\text { child and } \\
\text { sometimes have } \\
\text { zero appetite }\end{array}$} & \multicolumn{3}{|c|}{$\begin{array}{l}\text { Means you } \\
\text { expected to be } \\
\text { a better child to } \\
\text { help your } \\
\text { parents but you } \\
\text { let them down } \\
\text { by getting } \\
\text { pregnant and } \\
\text { make them feel } \\
\text { bad }\end{array}$} & \multicolumn{3}{|c|}{$\begin{array}{l}\text { Means you arє } \\
\text { over-thinking i } \\
\text { your head and } \\
\text { can't } \\
\text { concentrate or } \\
\text { one item }\end{array}$} \\
\hline & & C & $\mathbf{R}$ & $J$ & C & $\mathbf{R}$ & $J$ & C & $\mathbf{R}$ & $J$ & C & $\mathbf{R}$ & J & $\mathrm{C}$ & $\mathbf{R}$ & $J$ & C & $\mathbf{R}$ & $J$ & C & $\mathbf{R}$ & $J$ \\
\hline & & 1 & 1 & 1 & 1 & 1 & 1 & 1 & 1 & 1 & 2 & 2 & 2 & 1 & 1 & 1 & 2 & 2 & 2 & 2 & 2 & 2 \\
\hline \multirow[t]{3}{*}{ KII AD 04 KR } & $\begin{array}{l}18 \text { Yrs } \\
\text { Child } 1 \\
\text { month }\end{array}$ & \multicolumn{3}{|c|}{$\begin{array}{l}\text { There are } \\
\text { changes in } \\
\text { watching Tv } \\
\text { due to baby }\end{array}$} & \multicolumn{3}{|c|}{$\begin{array}{l}\text { It means you } \\
\text { are stressed } \\
\text { and don't } \\
\text { know how to } \\
\text { sort the } \\
\text { problem } \\
\text { especially in } \\
\text { the past } \\
\text { compared to } \\
\text { present }\end{array}$} & \multicolumn{3}{|c|}{$\begin{array}{l}\text { Over-thinking as } \\
\text { the father of the } \\
\text { child is not } \\
\text { supportive }\end{array}$} & \multicolumn{3}{|c|}{$\begin{array}{l}\text { Means you } \\
\text { don't have } \\
\text { moods } \\
\text { (remains } \\
\text { being bad } \\
\text { experience } \\
\text { and loss of } \\
\text { interest) }\end{array}$} & \multicolumn{3}{|c|}{$\begin{array}{l}\text { Loss of appetite } \\
\text { due to choose of } \\
\text { food, and stress, } \\
\text { insults or lack of } \\
\text { partner support }\end{array}$} & \multicolumn{3}{|c|}{$\begin{array}{l}\text { I feel like I have } \\
\text { let down my } \\
\text { family }\end{array}$} & \multicolumn{3}{|c|}{$\begin{array}{l}\text { Due to over- } \\
\text { thinking about } \\
\text { impossible } \\
\text { things, no } \\
\text { money to eat } \\
\text { something for } \\
\text { the child and } \\
\text { no plan }\end{array}$} \\
\hline & & C & $\mathbf{R}$ & $J$ & C & $\mathbf{R}$ & $J$ & C & $\mathbf{R}$ & $J$ & C & $\mathbf{R}$ & $J$ & C & $\mathbf{R}$ & $J$ & C & $\mathbf{R}$ & $\mathbf{J}$ & C & $\mathbf{R}$ & $J$ \\
\hline & & 1 & 1 & 1 & 2 & 2 & 2 & 1 & 1 & 1 & 2 & 1 & 1 & 2 & 2 & 2 & 2 & 2 & 2 & 2 & 2 & 2 \\
\hline COG AD 03 KG & $\begin{array}{l}17 \text { Yrs } \\
5 \text { months } \\
\text { pregnant }\end{array}$ & \multicolumn{3}{|c|}{$\begin{array}{l}\text { Being lazy } \\
\text { to do any } \\
\text { activity }\end{array}$} & \multicolumn{3}{|c|}{$\begin{array}{l}\text { No moods } \\
\text { (feeling like } \\
\text { sleeping and } \\
\text { also waking) }\end{array}$} & \multicolumn{3}{|c|}{$\begin{array}{l}\text { Sleeping both } \\
\text { day and night }\end{array}$} & \multicolumn{3}{|c|}{$\begin{array}{l}\text { You wake } \\
\text { up tired } \\
\text { after sleep } \\
\text { not work }\end{array}$} & \multicolumn{3}{|c|}{$\begin{array}{l}\text { Low appetite } \\
\text { and your heart } \\
\text { feels like you } \\
\text { don't want to }\end{array}$} & \multicolumn{3}{|c|}{$\begin{array}{l}\text { When someone } \\
\text { gets pregnant } \\
\text { while young } \\
\text { they get } \\
\text { discouraged }\end{array}$} & \multicolumn{3}{|c|}{$\begin{array}{l}\text { The } \\
\text { concentration } \\
\text { of someone } \\
\text { (low or high) }\end{array}$} \\
\hline
\end{tabular}

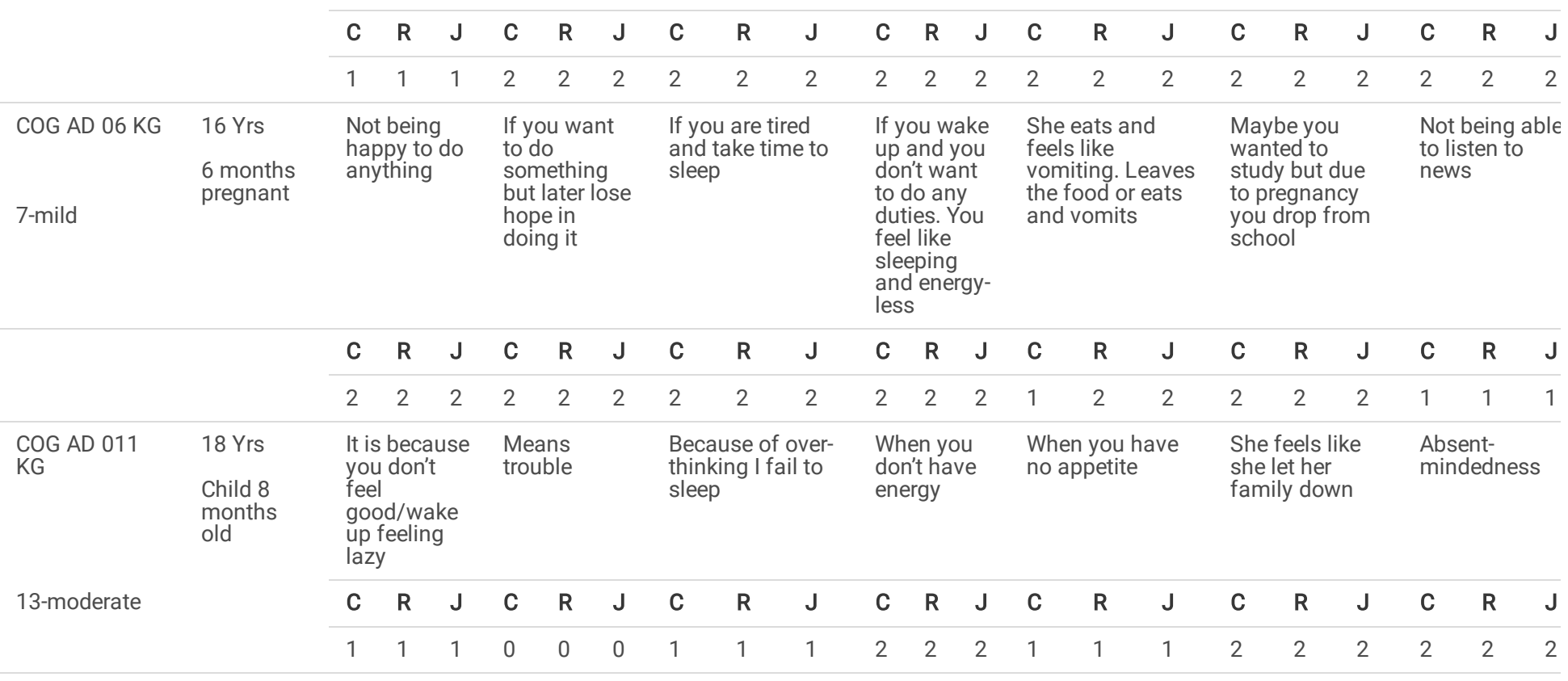




\begin{tabular}{|c|c|c|c|c|c|c|c|c|c|c|c|c|c|c|c|c|c|c|c|c|c|}
\hline \multirow{3}{*}{$\begin{array}{l}\text { COG AD } 013 \\
\text { KG } \\
\text { 17-severely } \\
\text { moderate }\end{array}$} & \multirow{3}{*}{$\begin{array}{l}16 \text { Yrs } \\
5 \text { months } \\
\text { pregnant }\end{array}$} & \multicolumn{3}{|c|}{$\begin{array}{l}\text { Loss of } \\
\text { interest to } \\
\text { do any work }\end{array}$} & \multicolumn{3}{|c|}{$\begin{array}{l}\text { To have } \\
\text { many } \\
\text { problems } \\
\text { and to lose } \\
\text { hope }\end{array}$} & \multicolumn{3}{|c|}{$\begin{array}{l}\text { When you go to } \\
\text { sleep and start } \\
\text { over-thinking }\end{array}$} & \multicolumn{3}{|c|}{$\begin{array}{l}\text { She reports } \\
\text { getting tired } \\
\text { a lot as she } \\
\text { does all } \\
\text { chores }\end{array}$} & \multicolumn{3}{|c|}{$\begin{array}{l}\text { It means not } \\
\text { being able to eat }\end{array}$} & \multicolumn{3}{|c|}{$\begin{array}{l}\text { Feels a failure } \\
\text { as she dropped } \\
\text { from school } \\
\text { class } 8 \text { in } 2016\end{array}$} & \multicolumn{2}{|c|}{$\begin{array}{l}\text { She is always } \\
\text { doing her } \\
\text { things on time } \\
\text { and well }\end{array}$} \\
\hline & & C & $\mathbf{R}$ & $J$ & C & $\mathbf{R}$ & $J$ & C & $\mathbf{R}$ & $J$ & C & $\mathbf{R}$ & $J$ & C & $\mathbf{R}$ & $\mathbf{J}$ & C & $\mathbf{R}$ & $\mathbf{J}$ & C & $\mathbf{R}$ \\
\hline & & 1 & 0 & 0 & 2 & 1 & 1 & 2 & 2 & 2 & 2 & 2 & 2 & 2 & 2 & 2 & 2 & 2 & 2 & 2 & 2 \\
\hline \multirow[t]{3}{*}{$\begin{array}{l}\text { COG AD } 014 \\
\text { KG }\end{array}$} & $\begin{array}{l}18 \text { Yrs } \\
\text { Child } 2 \\
\text { months } \\
\text { old }\end{array}$ & \multicolumn{3}{|c|}{$\begin{array}{l}\text { Little time to } \\
\text { do things }\end{array}$} & \multicolumn{3}{|c|}{ Not at peace } & \multicolumn{3}{|c|}{$\begin{array}{l}\text { If the child cries } \\
\text { a lot you also } \\
\text { don't get sleep. } \\
\text { Worries that } \\
\text { baby is sick }\end{array}$} & \multicolumn{3}{|c|}{$\begin{array}{l}\text { When you } \\
\text { are tired } \\
\text { and low } \\
\text { energy in } \\
\text { your body }\end{array}$} & \multicolumn{3}{|c|}{$\begin{array}{l}\text { Does not feel } \\
\text { hungry to eat. } \\
\text { Overeating is } \\
\text { eating a lot }\end{array}$} & \multicolumn{3}{|c|}{$\begin{array}{l}\text { To feel bad } \\
\text { about your } \\
\text { body/self or } \\
\text { feeling that you } \\
\text { are a } \\
\text { disappointment } \\
\text { to self and your } \\
\text { family }\end{array}$} & \multicolumn{2}{|c|}{$\begin{array}{l}\text { Difficulty to } \\
\text { follow } \\
\text { anything. } \\
\text { Maybe the } \\
\text { person is } \\
\text { engaged in } \\
\text { deep thoughts }\end{array}$} \\
\hline & & C & $\mathbf{R}$ & $J$ & $\mathrm{C}$ & $\mathbf{R}$ & $J$ & C & $\mathbf{R}$ & $J$ & C & $\mathbf{R}$ & $J$ & C & $\mathbf{R}$ & $J$ & C & $\mathbf{R}$ & $J$ & C & $\mathbf{R}$ \\
\hline & & 1 & 1 & 1 & 1 & 1 & 1 & 2 & 2 & 2 & 2 & 2 & 2 & 2 & 2 & 2 & 2 & 2 & 2 & 2 & 1 \\
\hline \multirow[t]{3}{*}{$\begin{array}{l}\text { COG AD } 021 \\
\text { KG }\end{array}$} & $\begin{array}{l}15 \text { Yrs } \\
\text { Child } 9 \\
\text { months }\end{array}$ & \multicolumn{3}{|c|}{$\begin{array}{l}\text { When one } \\
\text { lives in a } \\
\text { mistreated } \\
\text { environment }\end{array}$} & \multicolumn{3}{|c|}{$\begin{array}{l}\text { She } \\
\text { sometimes } \\
\text { feels } \\
\text { hopeless but } \\
\text { mother } \\
\text { spoke to her }\end{array}$} & \multicolumn{3}{|c|}{$\begin{array}{l}\text { Lacks sleep due } \\
\text { to thinking }\end{array}$} & \multicolumn{3}{|c|}{$\begin{array}{l}\text { She works } \\
\text { hard and } \\
\text { gets paid } \\
\text { less for } \\
\text { many hours }\end{array}$} & \multicolumn{3}{|c|}{$\begin{array}{l}\text { She eats well } \\
\text { only if she } \\
\text { doesn't have } \\
\text { work but not due } \\
\text { to stress }\end{array}$} & \multicolumn{3}{|c|}{$\begin{array}{l}\text { She has let } \\
\text { down her } \\
\text { family as if she } \\
\text { had studied } \\
\text { would get a } \\
\text { better job so } \\
\text { that her family } \\
\text { is better off }\end{array}$} & \multicolumn{2}{|c|}{$\begin{array}{l}\text { She reports } \\
\text { when she is } \\
\text { rushed/shout } \\
\text { at she get } \\
\text { confused }\end{array}$} \\
\hline & & C & $\mathbf{R}$ & $J$ & C & $\mathbf{R}$ & $J$ & C & $\mathbf{R}$ & $J$ & C & $\mathbf{R}$ & J & C & $\mathbf{R}$ & $J$ & C & $\mathbf{R}$ & $J$ & C & $\mathbf{R}$ \\
\hline & & 1 & 1 & 1 & 2 & 2 & 2 & 2 & 2 & 2 & 2 & 2 & 2 & 2 & 2 & 2 & 2 & 2 & 2 & 2 & 2 \\
\hline \multirow{2}{*}{$\begin{array}{l}\text { COG AD } 018 \\
\text { KG }\end{array}$} & 15 Yrs & \multirow{2}{*}{\multicolumn{3}{|c|}{$\begin{array}{l}\text { Waking up } \\
\text { lazy }\end{array}$}} & \multirow{2}{*}{\multicolumn{3}{|c|}{$\begin{array}{l}\text { Doesn't } \\
\text { comprehend } \\
\text { it all "feeling } \\
\text { down" is } \\
\text { hard }\end{array}$}} & \multirow{2}{*}{\multicolumn{3}{|c|}{$\begin{array}{l}\text { Stressed cannot } \\
\text { sleep due to } \\
\text { stress/pregnancy }\end{array}$}} & \multirow{2}{*}{\multicolumn{3}{|c|}{$\begin{array}{l}\text { She feels } \\
\text { lazy/feeling } \\
\text { "maybe I } \\
\text { am sick" } \\
\text { she forces } \\
\text { self to go to } \\
\text { work }\end{array}$}} & \multirow{2}{*}{\multicolumn{3}{|c|}{ Lacks appetite }} & \multirow{2}{*}{\multicolumn{3}{|c|}{$\begin{array}{l}\text { She blames } \\
\text { self }\end{array}$}} & \multirow{2}{*}{\multicolumn{2}{|c|}{$\begin{array}{l}\text { Doesn't } \\
\text { understand }\end{array}$}} \\
\hline & $\begin{array}{l}7 \text { months } \\
\text { pregnant }\end{array}$ & & & & & & & & & & & & & & & & & & & & \\
\hline
\end{tabular}

\section{PHQ9-KISWAHILI VERSION}

\begin{tabular}{|c|c|c|c|c|c|c|c|c|c|c|c|c|c|c|c|c|c|c|c|c|c|c|}
\hline \multirow[t]{3}{*}{$\begin{array}{l}\text { COG AD } 07 \text { KG } \\
\text { 10-moderate }\end{array}$} & \multirow[t]{3}{*}{$\begin{array}{l}16 \text { Yrs } \\
7 \text { months } \\
\text { pregnant }\end{array}$} & \multicolumn{3}{|c|}{$\begin{array}{l}\text { When } \\
\text { someone } \\
\text { does } \\
\text { something } \\
\text { but it } \\
\text { doesn't } \\
\text { please her }\end{array}$} & \multicolumn{3}{|c|}{ Giving up } & \multicolumn{3}{|c|}{$\begin{array}{l}\text { Sleeping all the } \\
\text { time }\end{array}$} & \multicolumn{3}{|c|}{$\begin{array}{l}\text { Feeling so } \\
\text { much tired } \\
\text { or reduction } \\
\text { in energy }\end{array}$} & \multicolumn{3}{|c|}{$\begin{array}{l}\text { When somebody } \\
\text { lacks appetite } \\
\text { for food or eats } \\
\text { a lot }\end{array}$} & \multicolumn{3}{|c|}{$\begin{array}{l}\text { Feeling bad or } \\
\text { making your } \\
\text { family feel bad } \\
\text { about } \\
\text { something }\end{array}$} & \multicolumn{3}{|c|}{$\begin{array}{l}\text { Paying } \\
\text { attention while } \\
\text { doing } \\
\text { something or } \\
\text { reading }\end{array}$} \\
\hline & & C & $\mathbf{R}$ & $J$ & C & $\mathbf{R}$ & $J$ & C & $\mathbf{R}$ & $J$ & C & $\mathbf{R}$ & $J$ & C & $\mathbf{R}$ & $J$ & C & $\mathbf{R}$ & $J$ & C & $\mathbf{R}$ & $J$ \\
\hline & & 1 & 2 & 2 & 2 & 2 & 2 & 2 & 2 & 2 & 2 & 2 & 2 & 2 & 2 & 2 & 2 & 2 & 2 & 1 & 1 & 1 \\
\hline $\begin{array}{l}\text { 15-severely } \\
\text { moderate }\end{array}$ & $\begin{array}{l}17 \text { Yrs } \\
7 \text { months } \\
\text { pregnant }\end{array}$ & \multicolumn{3}{|c|}{$\begin{array}{l}\text { Means you } \\
\text { don't have } \\
\text { time or don't } \\
\text { feel like }\end{array}$} & \multicolumn{3}{|c|}{$\begin{array}{l}\text { I haven't } \\
\text { understood }\end{array}$} & \multicolumn{3}{|c|}{ Sleeping issues } & \multicolumn{3}{|c|}{$\begin{array}{l}\text { Means you } \\
\text { are } \\
\text { extremely } \\
\text { tired and } \\
\text { don't feel } \\
\text { like doing } \\
\text { anything } \\
\text { else }\end{array}$} & \multicolumn{3}{|c|}{$\begin{array}{l}\text { That one is } \\
\text { overeating }\end{array}$} & \multicolumn{3}{|c|}{$\begin{array}{l}\text { I haven't } \\
\text { understood it }\end{array}$} & \multicolumn{3}{|c|}{$\begin{array}{l}\text { Means for } \\
\text { example if I } \\
\text { take a paper tc } \\
\text { read it may } \\
\text { reach a time } \\
\text { when I fail to } \\
\text { focus on that } \\
\text { paper and star } \\
\text { looking at it bi } \\
\text { can't read }\end{array}$} \\
\hline
\end{tabular}

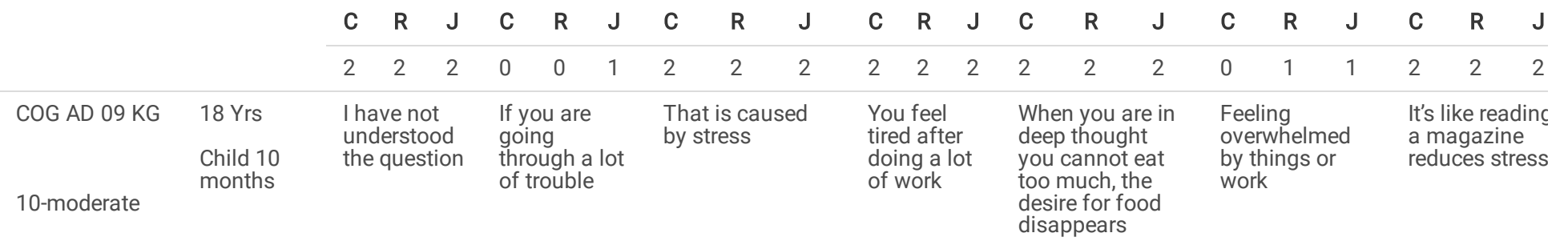

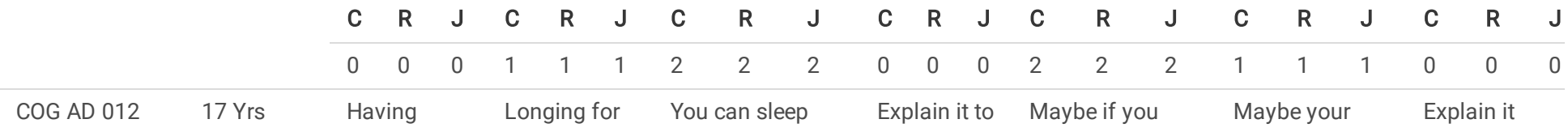




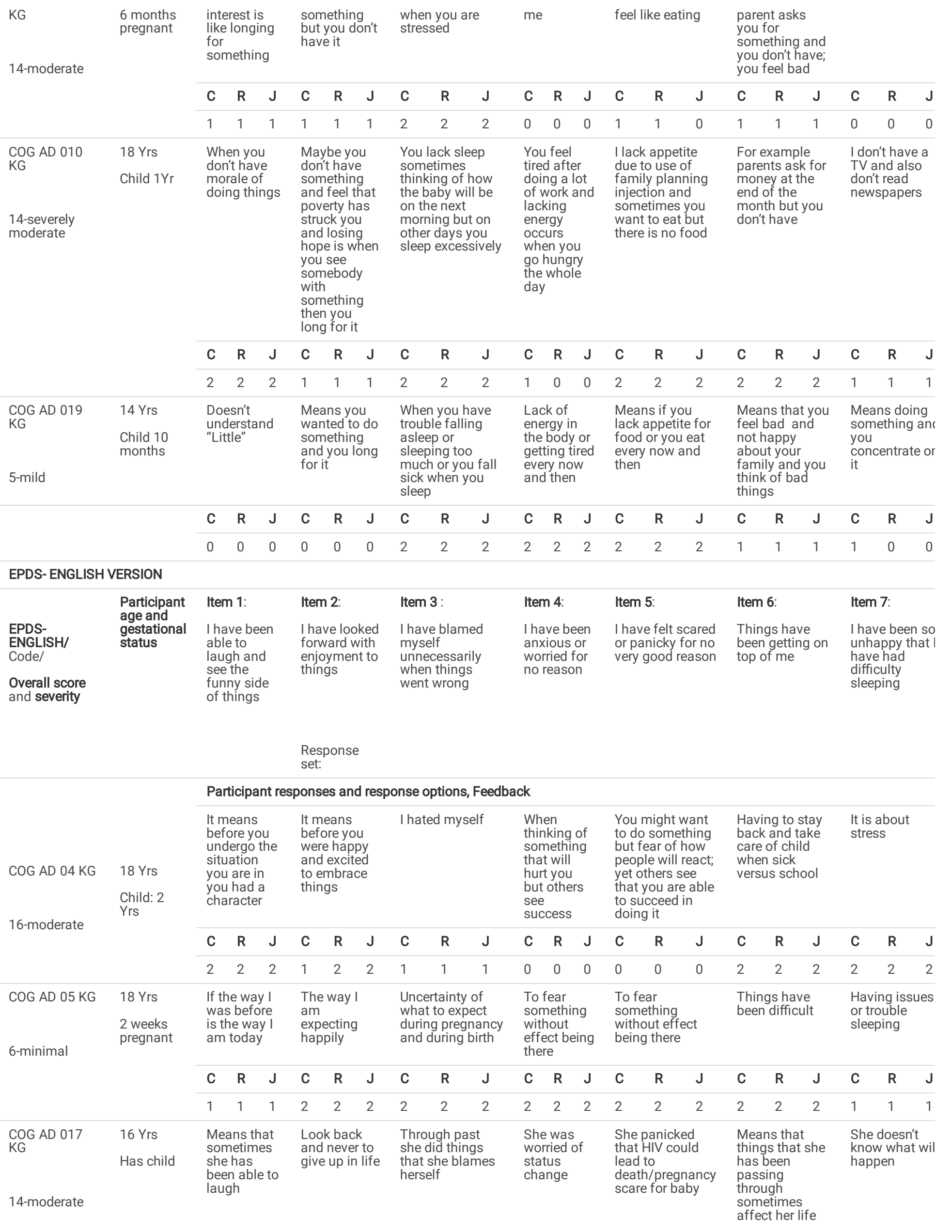




\begin{tabular}{|c|c|c|c|c|c|c|c|c|c|c|c|c|c|c|c|c|c|c|c|c|c|c|}
\hline & & & & & & & & & & & & & & & & & & & & & & \\
\hline & & C & $\mathbf{R}$ & $\mathbf{J}$ & C & $\mathbf{R}$ & $J$ & C & $\mathbf{R}$ & $\mathbf{J}$ & C & $\mathbf{R}$ & $\mathbf{J}$ & C & $\mathbf{R}$ & $\mathbf{J}$ & C & $\mathbf{R}$ & $J$ & C & $\mathbf{R}$ & $J$ \\
\hline & & 2 & 2 & 2 & 2 & 2 & 2 & 2 & 2 & 2 & 2 & 2 & 2 & 2 & 2 & 2 & 2 & 2 & 2 & 1 & 1 & 1 \\
\hline KII AD 02 KR & & \multirow{2}{*}{\multicolumn{3}{|c|}{$\begin{array}{l}\text { It means } \\
\text { that I am } \\
\text { still happy } \\
\text { just the way } \\
\text { I was before }\end{array}$}} & \multirow{2}{*}{\multicolumn{3}{|c|}{$\begin{array}{l}\text { If my child } \\
\text { grows and I } \\
\text { get a job I } \\
\text { will carry the } \\
\text { child on the } \\
\text { back and } \\
\text { others can } \\
\text { help }\end{array}$}} & \multirow{2}{*}{\multicolumn{3}{|c|}{$\begin{array}{l}\text { Dependence on } \\
\text { her mother } \\
\text { makes her feel } \\
\text { bad }\end{array}$}} & \multirow{2}{*}{\multicolumn{3}{|c|}{$\begin{array}{l}\text { The worries } \\
\text { that the } \\
\text { child starts } \\
\text { to feed yet } \\
\text { there are no } \\
\text { funds }\end{array}$}} & \multirow{2}{*}{\multicolumn{3}{|c|}{$\begin{array}{l}\text { She gets startled } \\
\text { because she } \\
\text { wants things but } \\
\text { cannot ask }\end{array}$}} & \multirow{2}{*}{\multicolumn{3}{|c|}{$\begin{array}{l}\text { The } \\
\text { requirements } \\
\text { are more than } \\
\text { resources. One } \\
\text { person } \\
\text { supports } \\
\text { (mum) hence } \\
\text { feels like a } \\
\text { burden }\end{array}$}} & \multirow{2}{*}{\multicolumn{3}{|c|}{$\begin{array}{l}\text { If she has a } \\
\text { problem it } \\
\text { means that sh } \\
\text { has to step up }\end{array}$}} \\
\hline 13-mild & $\begin{array}{l}\text { Child } 2 \\
\text { months }\end{array}$ & & & & & & & & & & & & & & & & & & & & & \\
\hline
\end{tabular}

\begin{tabular}{|c|c|c|c|c|c|c|c|c|c|c|c|c|c|c|c|c|c|c|c|c|c|c|}
\hline & & C & $\mathbf{R}$ & $\mathbf{J}$ & C & $\mathbf{R}$ & $\mathbf{J}$ & C & $\mathbf{R}$ & $\mathbf{J}$ & C & $\mathbf{R}$ & $\mathbf{J}$ & C & $\mathbf{R}$ & $\mathbf{J}$ & C & $\mathbf{R}$ & I & C & $\mathbf{R}$ & $\mathbf{J}$ \\
\hline & & 2 & 2 & 2 & 1 & 1 & 1 & 2 & 2 & 2 & 2 & 2 & 2 & 2 & 2 & 2 & 2 & 2 & 2 & 0 & 0 & 0 \\
\hline COG AD 022 & & & h & & & an s & & & & & & & & & & o & & & & & & \\
\hline & $\begin{array}{l}\text { Child } 6 \\
\text { months } \\
\text { old }\end{array}$ & $\begin{array}{l}\text { lau } \\
\text { se } \\
\text { as }\end{array}$ & $\begin{array}{l}\text { ha } \\
\text { thir } \\
\text { unr }\end{array}$ & & & & & $\begin{array}{l}\text { so } \\
\text { or } \\
\mathrm{m}\end{array}$ & $\begin{array}{l}\text { thit } \\
\text { her }\end{array}$ & $\begin{array}{l}\text { bad } \\
\text { a }\end{array}$ & & $\begin{array}{l}\text { time } \\
\text { lout } \\
\text { son }\end{array}$ & & & I ar & kay & & & & & slee & \\
\hline
\end{tabular}

8-mild

$\begin{array}{lllllllllllllllllllll}\mathbf{C} & \mathbf{R} & \mathbf{J} & \mathbf{C} & \mathbf{R} & \mathbf{J} & \mathbf{C} & \mathbf{R} & \mathbf{J} & \mathbf{C} & \mathbf{R} & \mathbf{J} & \mathbf{C} & \mathbf{R} & \mathbf{J} & \mathbf{C} & \mathbf{R} & \mathbf{J} & \mathbf{C} & \mathbf{R} & \mathbf{J} \\ 2 & 2 & 2 & 1 & 1 & 1 & 2 & 2 & 2 & 2 & 2 & 2 & 1 & 1 & 1 & 0 & 0 & 0 & 2 & 2 & 2\end{array}$

COG AD $023 \quad 16$ Yrs

KG

\section{5 months} pregnant

\section{Doesn't}

understand understand

was re-read was re-read

severally)

8-mild

\begin{tabular}{|c|c|c|c|c|c|c|c|c|c|c|c|c|c|c|c|c|c|c|c|c|}
\hline C & $\mathbf{R}$ & $\mathbf{J}$ & C & $\mathbf{R}$ & $\mathbf{J}$ & C & $\mathbf{R}$ & $\mathbf{J}$ & C & $\mathbf{R}$ & $\mathbf{J}$ & C & $\mathbf{R}$ & $\mathbf{J}$ & C & $\mathbf{R}$ & $\mathbf{J}$ & C & $\mathbf{R}$ & $\mathbf{J}$ \\
\hline 0 & 0 & 0 & 0 & 0 & 0 & 0 & 0 & 0 & 0 & 1 & 1 & 0 & 0 & 0 & 0 & 0 & 0 & 0 & 0 & 0 \\
\hline \multicolumn{3}{|c|}{$\begin{array}{l}\text { "seeing the } \\
\text { funny side } \\
\text { of things" is } \\
\text { difficult to }\end{array}$} & \multicolumn{3}{|c|}{$\begin{array}{l}\text { Waiting for } \\
\text { the } \\
\text { pregnancy } \\
\text { with joy }\end{array}$} & \multicolumn{3}{|c|}{$\begin{array}{l}\text { Complaining to } \\
\text { myself when } \\
\text { things go wrong }\end{array}$} & \multicolumn{3}{|c|}{$\begin{array}{l}\text { It is difficult } \\
\text { to } \\
\text { understand } \\
\text { "anxious" }\end{array}$} & \multicolumn{3}{|c|}{$\begin{array}{l}\text { "Panicky" is } \\
\text { difficult to } \\
\text { understand }\end{array}$} & \multicolumn{3}{|c|}{$\begin{array}{l}\text { Things that are } \\
\text { continuing to } \\
\text { happen to me }\end{array}$} & \multicolumn{3}{|c|}{$\begin{array}{l}\text { Doesn't } \\
\text { understand } \\
\text { "unhappy" }\end{array}$} \\
\hline
\end{tabular}

15-moderate

understand

Doesn't

understand

know the

(Question was re-

read severally)
Doesn't
know the
meaning of

Doesn't
understand

(Question was

Question was
re-read severally)
The whole

question is

hard
Doesn't

understand

(Question was re-read severally)

\begin{tabular}{|c|c|c|c|c|c|c|c|c|c|c|c|c|c|c|c|c|c|c|c|c|c|c|}
\hline \multirow[t]{3}{*}{$\begin{array}{l}\text { COG AD } 024 \\
\text { KG } \\
\text { 15-moderate }\end{array}$} & \multirow[t]{3}{*}{$\begin{array}{l}6 \text { months } \\
\text { pregnant }\end{array}$} & \multicolumn{3}{|c|}{$\begin{array}{l}\text { "seeing the } \\
\text { funny side } \\
\text { of things" is } \\
\text { difficult to } \\
\text { understand }\end{array}$} & \multicolumn{3}{|c|}{$\begin{array}{l}\text { Waiting for } \\
\text { the } \\
\text { pregnancy } \\
\text { with joy }\end{array}$} & \multicolumn{3}{|c|}{$\begin{array}{l}\text { Complaining to } \\
\text { myself when } \\
\text { things go wrong }\end{array}$} & \multicolumn{3}{|c|}{$\begin{array}{l}\text { It is difficult } \\
\text { to } \\
\text { understand } \\
\text { "anxious" }\end{array}$} & \multicolumn{3}{|c|}{$\begin{array}{l}\text { "Panicky" is } \\
\text { difficult to } \\
\text { understand }\end{array}$} & \multicolumn{3}{|c|}{$\begin{array}{l}\text { Things that are } \\
\text { continuing to } \\
\text { happen to me }\end{array}$} & \multicolumn{3}{|c|}{$\begin{array}{l}\text { Doesn't } \\
\text { understand } \\
\text { "unhappy" }\end{array}$} \\
\hline & & C & $\mathbf{R}$ & $\mathrm{J}$ & C & $\mathbf{R}$ & $\mathrm{J}$ & C & $\mathbf{R}$ & $\mathrm{J}$ & C & $\mathbf{R}$ & J & C & $\mathbf{R}$ & $\mathbf{J}$ & C & $\mathbf{R}$ & $\mathrm{J}$ & C & $\mathbf{R}$ & $J$ \\
\hline & & 1 & 1 & 1 & 0 & 0 & 0 & 2 & 2 & 2 & 0 & 1 & 1 & 0 & 1 & 1 & 1 & 1 & 1 & 0 & 0 & 0 \\
\hline \multirow{2}{*}{$\begin{array}{l}\text { COG AD } 025 \\
\text { KG }\end{array}$} & 15 Yrs & \multirow{2}{*}{\multicolumn{3}{|c|}{$\begin{array}{l}\text { It is when } \\
\text { she has had } \\
\text { happy } \\
\text { moments }\end{array}$}} & \multirow{2}{*}{\multicolumn{3}{|c|}{$\begin{array}{l}\text { Due to baby } \\
\text { responsibility } \\
\text { she has to } \\
\text { work hard } \\
\text { and have } \\
\text { hope }\end{array}$}} & \multirow{2}{*}{\multicolumn{3}{|c|}{$\begin{array}{l}\text { If she had not } \\
\text { had sex with that } \\
\text { guy she would } \\
\text { not have a baby } \\
\text { now }\end{array}$}} & \multirow{2}{*}{\multicolumn{3}{|c|}{$\begin{array}{l}\text { Worried } \\
\text { about after- } \\
\text { math }\end{array}$}} & \multirow{2}{*}{\multicolumn{3}{|c|}{$\begin{array}{l}\text { Worries/scared } \\
\text { of future }\end{array}$}} & \multirow{2}{*}{\multicolumn{3}{|c|}{$\begin{array}{l}\text { If she had a } \\
\text { partner she } \\
\text { would be able } \\
\text { to carry the big } \\
\text { load rather } \\
\text { than alone }\end{array}$}} & \multirow{2}{*}{\multicolumn{3}{|c|}{$\begin{array}{l}\text { Too much } \\
\text { thoughts (not } \\
\text { eating, } \\
\text { headache) }\end{array}$}} \\
\hline & $\begin{array}{l}\text { Child } 10 \\
\text { months }\end{array}$ & & & & & & & & & & & & & & & & & & & & & \\
\hline
\end{tabular}

\begin{tabular}{|c|c|c|c|c|c|c|c|c|c|c|c|c|c|c|c|c|c|c|c|c|c|c|}
\hline & C & $\mathbf{R}$ & $\mathbf{J}$ & C & $\mathbf{R}$ & $J$ & C & $\mathbf{R}$ & $\mathrm{J}$ & C & $\mathbf{R}$ & $\mathbf{J}$ & C & $\mathbf{R}$ & $J$ & C & $\mathbf{R}$ & $\mathbf{J}$ & C & $\mathbf{R}$ & $J$ \\
\hline & & 2 & 2 & 2 & 1 & 1 & 1 & 2 & 2 & 2 & 2 & 2 & 2 & 1 & 1 & 1 & 1 & 1 & 1 & 2 & 2 & 2 \\
\hline \multirow{4}{*}{$\begin{array}{l}\text { COG AD } 026 \\
\text { KG }\end{array}$} & & \multirow{2}{*}{\multicolumn{3}{|c|}{$\begin{array}{l}\text { I can laugh } \\
\text { but } \\
\text { sometimes I } \\
\text { am angry }\end{array}$}} & \multirow{2}{*}{\multicolumn{3}{|c|}{$\begin{array}{l}\text { I look } \\
\text { forward to } \\
\text { things now } \\
\text { that I am } \\
\text { with my } \\
\text { husband }\end{array}$}} & \multirow{2}{*}{\multicolumn{3}{|c|}{$\begin{array}{l}\text { Blamed herself } \\
\text { for taking ARVs } \\
\text { from birth yet her } \\
\text { sister was fine }\end{array}$}} & \multirow{2}{*}{\multicolumn{3}{|c|}{$\begin{array}{l}\text { Understood } \\
\text { though no } \\
\text { past } \\
\text { experiences }\end{array}$}} & \multirow{2}{*}{\multicolumn{3}{|c|}{$\begin{array}{l}\text { Understood } \\
\text { though no past } \\
\text { experiences }\end{array}$}} & \multirow{2}{*}{\multicolumn{3}{|c|}{$\begin{array}{l}\text { She felt she } \\
\text { needed support } \\
\text { for education } \\
\text { before }\end{array}$}} & \multirow{2}{*}{\multicolumn{3}{|c|}{$\begin{array}{l}\text { Her husband } \\
\text { beat her but } \\
\text { later } \\
\text { apologized }\end{array}$}} \\
\hline & \multirow[t]{3}{*}{$\begin{array}{l}\text { Child } 6 \\
\text { months }\end{array}$} & & & & & & & & & & & & & & & & & & & & & \\
\hline & & C & $\mathbf{R}$ & $\mathbf{J}$ & C & $\mathbf{R}$ & $\mathbf{J}$ & C & $\mathbf{R}$ & $\mathrm{J}$ & C & $\mathbf{R}$ & $\mathbf{J}$ & C & $\mathbf{R}$ & $J$ & C & $\mathbf{R}$ & $J$ & C & $\mathbf{R}$ & $\mathrm{J}$ \\
\hline & & 1 & 1 & 1 & 2 & 2 & 2 & 2 & 2 & 2 & 2 & 2 & 2 & 2 & 2 & 2 & 2 & 2 & 2 & 2 & 2 & 2 \\
\hline \multicolumn{23}{|c|}{ EPDS - KISWAHILI VERSION } \\
\hline \multirow{2}{*}{$\begin{array}{l}\text { COG AD } 016 \\
\text { KG }\end{array}$} & 16 Yrs & \multirow{2}{*}{\multicolumn{3}{|c|}{$\begin{array}{l}\text { If you have } \\
\text { laughed } \\
\text { because } \\
\text { you have } \\
\text { seen things }\end{array}$}} & \multirow{2}{*}{\multicolumn{3}{|c|}{$\begin{array}{l}\text { You are used } \\
\text { to be happy } \\
\text { now you } \\
\text { expect that } \\
\text { you will be } \\
\text { happy }\end{array}$}} & \multirow{2}{*}{\multicolumn{3}{|c|}{$\begin{array}{l}\text { If you were not } \\
\text { used to blaming } \\
\text { yourself }\end{array}$}} & \multirow{2}{*}{\multicolumn{3}{|c|}{$\begin{array}{l}\text { If you never } \\
\text { liked being } \\
\text { worried }\end{array}$}} & \multirow{2}{*}{\multicolumn{3}{|c|}{$\begin{array}{l}\text { In the past you } \\
\text { were not scared } \\
\text { or anxious }\end{array}$}} & \multirow{2}{*}{\multicolumn{3}{|c|}{$\begin{array}{l}\text { In the past you } \\
\text { never used to } \\
\text { face issues but } \\
\text { now you are } \\
\text { facing them }\end{array}$}} & \multirow{2}{*}{\multicolumn{3}{|c|}{$\begin{array}{l}\text { Lack of sleep } \\
\text { due to several } \\
\text { issues such as } \\
\text { thoughts }\end{array}$}} \\
\hline & $\begin{array}{l}8 \text { months } \\
\text { pregnant }\end{array}$ & & & & & & & & & & & & & & & & & & & & & \\
\hline
\end{tabular}

16-moderate 


\begin{tabular}{|c|c|c|c|c|c|c|c|c|}
\hline $\begin{array}{l}\text { COG AD } 08 \text { KG } \\
\text { 0-minimal }\end{array}$ & $\begin{array}{l}17 \text { Yrs } \\
6 \text { months } \\
\text { pregnant }\end{array}$ & $\begin{array}{l}\text { If I have } \\
\text { seen } \\
\text { something } \\
\text { enjoyable }\end{array}$ & $\begin{array}{l}\text { Maybe the } \\
\text { way that } \\
\text { thing turned } \\
\text { out is exactly } \\
\text { what I had } \\
\text { expected }\end{array}$ & $\begin{array}{l}\text { If I have blamed } \\
\text { myself for the } \\
\text { mistakes that } \\
\text { happened }\end{array}$ & $\begin{array}{l}\text { My being } \\
\text { disturbed } \\
\text { without any } \\
\text { issue }\end{array}$ & $\begin{array}{l}\text { Being afraid yet } \\
\text { there is no } \\
\text { existing problem }\end{array}$ & $\begin{array}{l}\text { If I have been } \\
\text { overwhelmed } \\
\text { with some few } \\
\text { issues }\end{array}$ & $\begin{array}{l}\text { If I have been } \\
\text { sad until I lack } \\
\text { the urge to } \\
\text { sleep }\end{array}$ \\
\hline
\end{tabular}

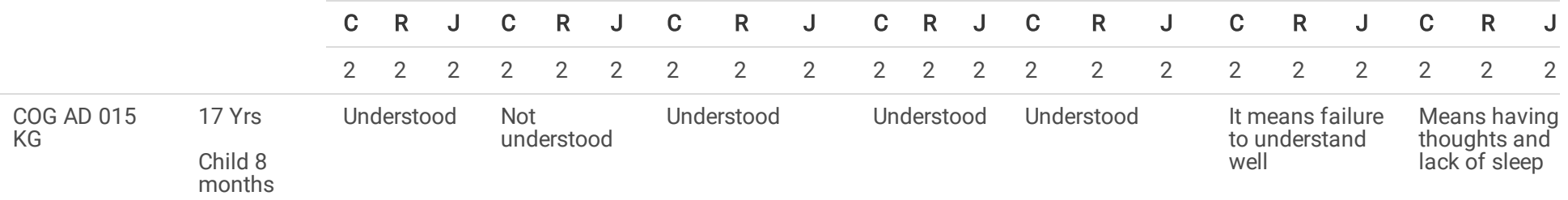

19-moderate

what I had

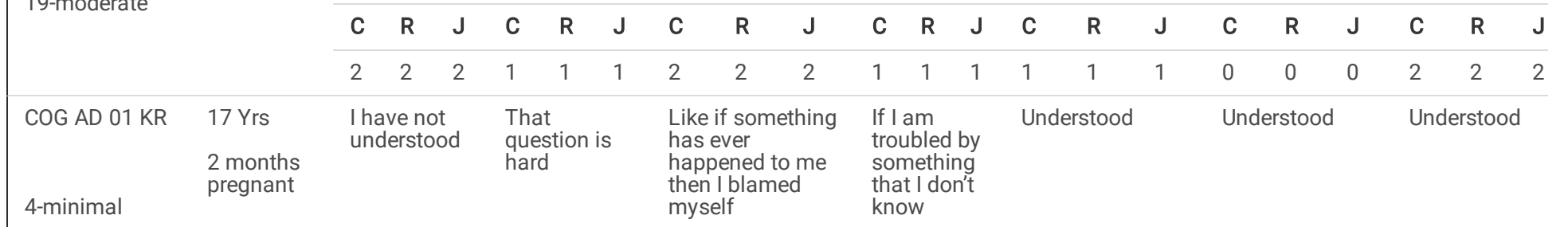

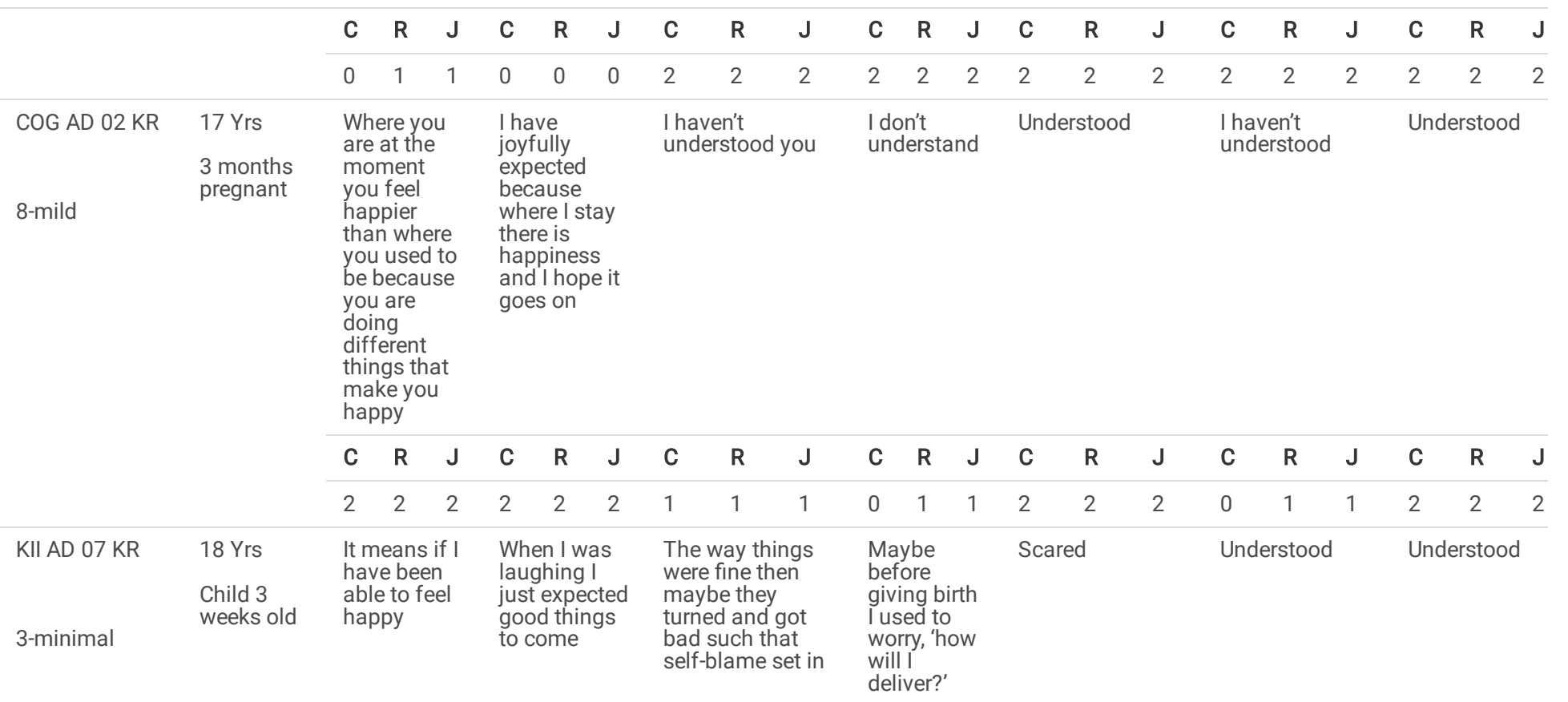

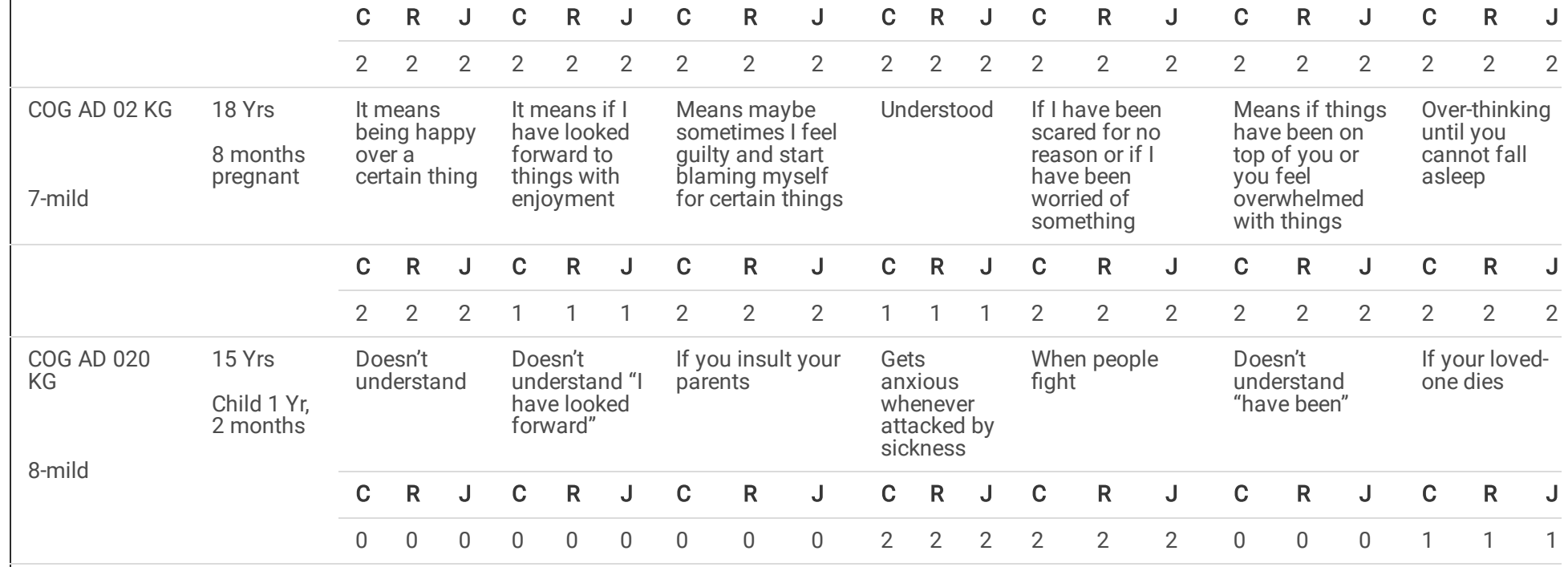


Table 4 Reliability of EPDS

\begin{tabular}{|c|c|c|c|c|c|c|c|c|c|c|c|c|}
\hline \multirow[t]{2}{*}{ EPDS Items } & \multirow[b]{2}{*}{$\begin{array}{l}\text { Scale } \\
\text { mean } \\
\text { if item } \\
\text { deleted }\end{array}$} & \multirow[b]{2}{*}{$\begin{array}{l}\text { Cronbach } \\
\text { alpha if } \\
\text { item } \\
\text { deleted }\end{array}$} & \multicolumn{4}{|c|}{ English } & \multirow[b]{2}{*}{$\begin{array}{l}\text { Cronbach's Alpha if } \\
\text { Item Deleted }\end{array}$} & \multicolumn{4}{|c|}{ Kiswahili } & \multirow[b]{2}{*}{$\begin{array}{l}\text { Cronbach's Alpha if } \\
\text { Item Deleted }\end{array}$} \\
\hline & & & Mean & S.D. & $\mathbf{N}$ & $\begin{array}{l}\text { Scale } \\
\text { Mean } \\
\text { if Item } \\
\text { Deleted }\end{array}$ & & Mean & S.D. & $\mathbf{N}$ & $\begin{array}{l}\text { Scale } \\
\text { Mean } \\
\text { if Item } \\
\text { Deleted }\end{array}$ & \\
\hline $\begin{array}{l}\text { 1. I have been } \\
\text { able to laugh } \\
\text { and see the } \\
\text { funny side of } \\
\text { things }\end{array}$ & 10.3 & 0.740 & 1.00 & 0.71 & 9 & 11.89 & 0.740 & 0.50 & 1.07 & 8 & 8.50 & 0.725 \\
\hline $\begin{array}{l}\text { 2. I have } \\
\text { looked } \\
\text { forward with } \\
\text { enjoyment to } \\
\text { things }\end{array}$ & 10.6 & 0.733 & 0.44 & 0.73 & 9 & 12.44 & 0.696 & 0.50 & 1.07 & 8 & 8.50 & 0.725 \\
\hline $\begin{array}{l}\text { 4. I have been } \\
\text { anxious or } \\
\text { worried for } \\
\text { no good } \\
\text { reason }\end{array}$ & 10.0 & 0.755 & 1.11 & 1.36 & 9 & 11.78 & 0.712 & 1.00 & 1.41 & 8 & 8.00 & 0.761 \\
\hline $\begin{array}{l}\text { * } 5 \text { I have felt } \\
\text { scared or } \\
\text { panicky for } \\
\text { no very good } \\
\text { reason }\end{array}$ & 10.1 & 0.779 & 1.11 & 1.27 & 9 & 11.78 & 0.765 & 0.88 & 1.13 & 8 & 8.13 & 0.776 \\
\hline $\begin{array}{l}\text { *6. Things } \\
\text { have been } \\
\text { getting on } \\
\text { top of me }\end{array}$ & 9.4 & 0.764 & 1.56 & 0.73 & 9 & 11.33 & 0.722 & 1.88 & 1.55 & 8 & 7.13 & 0.755 \\
\hline $\begin{array}{l}\text { *7 I have } \\
\text { been so } \\
\text { unhappy that } \\
\text { I have had } \\
\text { difficulty } \\
\text { sleeping }\end{array}$ & 9.8 & 0.796 & 1.56 & 1.33 & 9 & 11.33 & 0.793 & 1.00 & 1.07 & 8 & 8.00 & 0.795 \\
\hline $\begin{array}{l}\text { *8 I have felt } \\
\text { sad or } \\
\text { miserable }\end{array}$ & 9.8 & 0.725 & 1.89 & 1.05 & 9 & 11.00 & 0.739 & 0.63 & 0.74 & 8 & 8.38 & 0.699 \\
\hline $\begin{array}{l}* 9 \text { I have } \\
\text { been so } \\
\text { unhappy that } \\
\text { I have been } \\
\text { crying }\end{array}$ & 9.8 & 0.703 & 1.44 & 1.01 & 9 & 11.44 & 0.669 & 1.13 & 1.25 & 8 & 7.88 & 0.698 \\
\hline $\begin{array}{l}\text { * } 10 \text { The } \\
\text { thought of } \\
\text { harming } \\
\text { myself has } \\
\text { occurred to } \\
\text { me }\end{array}$ & 10.6 & 0.732 & 0.67 & 0.87 & 9 & 12.22 & 0.708 & 0.25 & 0.71 & 8 & 8.75 & 0.732 \\
\hline Total Score & & & 12.89 & 5.71 & 9 & & & 9.00 & 6.55 & 8 & & \\
\hline \multicolumn{3}{|c|}{ Combined Cronbach's Alpha 0.766} & & & & & 0.751 & & & & & 0.757 \\
\hline
\end{tabular}




\begin{tabular}{|c|c|c|c|c|c|c|c|c|c|c|c|c|}
\hline \multirow[t]{2}{*}{ PHQ-9 Items } & \multicolumn{6}{|c|}{ English } & \multicolumn{4}{|c|}{ Kiswahili } & \multirow[b]{2}{*}{$\begin{array}{l}\text { Scale } \\
\text { Mean } \\
\text { if Item } \\
\text { Deleted }\end{array}$} & \multirow[b]{2}{*}{$\begin{array}{l}\text { Cronbach's } \\
\text { Alpha if } \\
\text { Item } \\
\text { Deleted }\end{array}$} \\
\hline & $\begin{array}{l}\text { Scale } \\
\text { mean } \\
\text { if item } \\
\text { deleted }\end{array}$ & $\begin{array}{l}\text { Cronbach } \\
\text { alpha if } \\
\text { item } \\
\text { deleted }\end{array}$ & Mean & S.D & $\mathbf{N}$ & $\begin{array}{l}\text { Scale } \\
\text { Mean } \\
\text { if Item } \\
\text { Deleted }\end{array}$ & $\begin{array}{l}\text { Cronbach's } \\
\text { Alpha if } \\
\text { Item } \\
\text { Deleted }\end{array}$ & Mean & S.D & $\mathbf{N}$ & & \\
\hline $\begin{array}{l}\text { 1. Little interest or pleasure } \\
\text { in doing things }\end{array}$ & 10.67 & 0.501 & 1.56 & 0.88 & 9 & 10.89 & 0.635 & 1.00 & 0.89 & 6 & 10.33 & 0.292 \\
\hline $\begin{array}{l}\text { 2. Feeling down, depressed, } \\
\text { or hopeless }\end{array}$ & 10.93 & 0.482 & 1.11 & 1.05 & 9 & 11.33 & 0.587 & 1.00 & 1.10 & 6 & 10.33 & 0.385 \\
\hline $\begin{array}{l}\text { 3. Trouble falling or staying } \\
\text { asleep, or sleeping too much }\end{array}$ & 10.00 & 0.453 & 1.67 & 0.71 & 9 & 10.78 & 0.536 & 2.50 & 1.22 & 6 & 8.83 & 0.187 \\
\hline $\begin{array}{l}\text { 4. Feeling tired or having } \\
\text { little energy }\end{array}$ & 10.67 & 0.318 & 1.56 & 1.24 & 9 & 10.89 & 0.420 & 1.00 & 0.89 & 6 & 10.33 & 0.292 \\
\hline $\begin{array}{l}\text { 5. Poor appetite or } \\
\text { overeating }\end{array}$ & 10.07 & 0.557 & 1.89 & 1.05 & 9 & 10.56 & 0.687 & 2.00 & 1.26 & 6 & 9.33 & 0.282 \\
\hline $\begin{array}{l}\text { 6. Feeling bad about } \\
\text { yourself- or that you are a } \\
\text { failure or have let yourself or } \\
\text { your family down }\end{array}$ & 10.53 & 0.583 & 1.67 & 1.12 & 9 & 10.78 & 0.708 & 1.17 & 0.98 & 6 & 10.17 & 0.382 \\
\hline $\begin{array}{l}\text { 7. Trouble concentrating on } \\
\text { things, such as reading the } \\
\text { newspaper or watching } \\
\text { television }\end{array}$ & 10.93 & 0.644 & 1.11 & 1.36 & 9 & 11.33 & 0.606 & 1.00 & 1.10 & 6 & 10.33 & 0.760 \\
\hline $\begin{array}{l}\text { 8. Moving or speaking so } \\
\text { slowly that other people } \\
\text { could have noticed. Or the } \\
\text { opposite -being so fidgety or } \\
\text { restless that you have been } \\
\text { moving around a lot more } \\
\text { than usual }\end{array}$ & 10.87 & 0.568 & 0.89 & 0.60 & 9 & 11.56 & 0.571 & 1.50 & 1.05 & 6 & 9.83 & 0.601 \\
\hline $\begin{array}{l}\text { 9. Thoughts that you would } \\
\text { be better off dead, or of } \\
\text { hurting yourself }\end{array}$ & 11.33 & 0.580 & 1.00 & 1.00 & 9 & 11.44 & 0.658 & 0.17 & 0.41 & 6 & 11.17 & 0.525 \\
\hline Total Score & & & 12.44 & 4.69 & 9 & & & 11.33 & 4.08 & 6 & & \\
\hline \multicolumn{4}{|c|}{ Cronbach's Alpha combined 0.561} & & & & \multicolumn{3}{|l|}{0.640} & \multicolumn{3}{|c|}{0.495} \\
\hline
\end{tabular}

